\title{
LEVEL II SCOUR ANALYSIS FOR BRIDGE 96 (BLOOVT01050096) on VERMONT ROUTE 105, crossing the NULHEGAN RIVER, BLOOMFIELD, VERMONT
}

U.S. Geological Survey Open-File Report 96-566

Prepared in cooperation with

VERMONT AGENCY OF TRANSPORTATION and

FEDERAL HIGHWAY ADMINISTRATION 


\section{LEVEL II SCOUR ANALYSIS FOR BRIDGE 96 (BLOOVT01050096) on VERMONT ROUTE 105, crossing the NULHEGAN RIVER, BLOOMFIELD, VERMONT}

By JOSEPH D. AYOTTE AND MICHAEL A. IVANOFF

U.S. Geological Survey Open-File Report 96-566

Prepared in cooperation with

VERMONT AGENCY OF TRANSPORTATION and

FEDERAL HIGHWAY ADMINISTRATION 


\title{
U.S. DEPARTMENT OF THE INTERIOR BRUCE BABBITT, Secretary
}

\author{
U.S. GEOLOGICAL SURVEY \\ Gordon P. Eaton, Director
}

For additional information write to:

District Chief

U.S. Geological Survey 361 Commerce Way

Pembroke, NH 03275-3718
Copies of this report may be purchased from:

U.S. Geological Survey Earth Science Information Center Open-File Reports Section Box 25286, MS 517 Federal Center

Denver, CO 80225 


\section{CONTENTS}

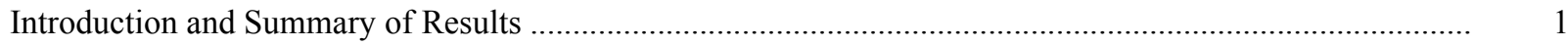

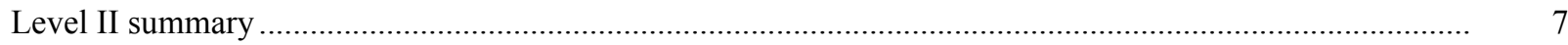

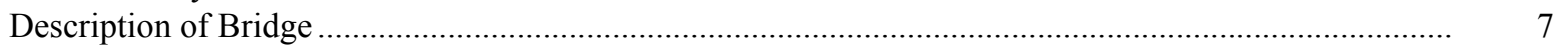

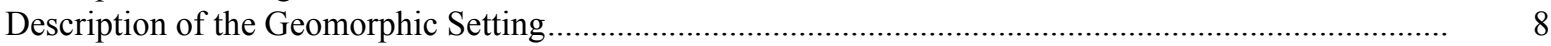

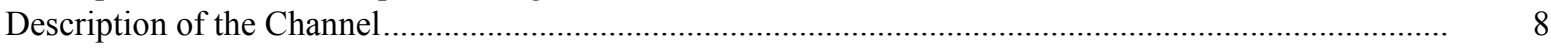

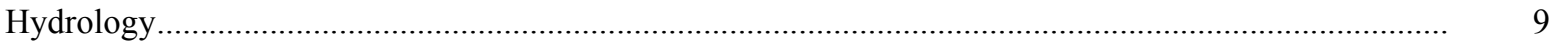

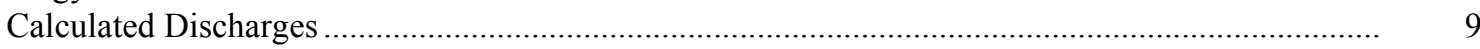

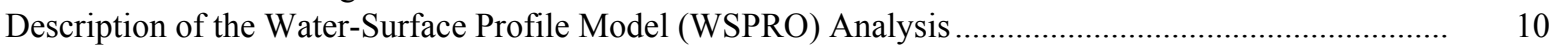

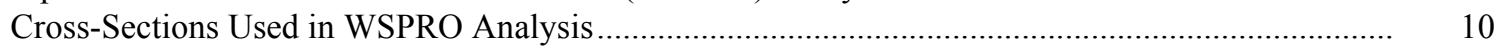

Data and Assumptions Used in WSPRO Model ...................................................................... 11

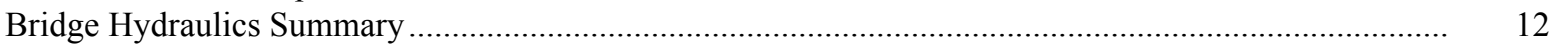

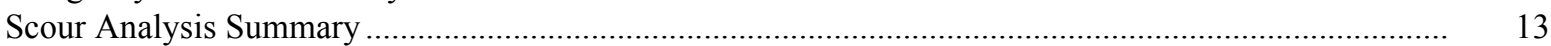

Special Conditions or Assumptions Made in Scour Analysis ...................................................... 13

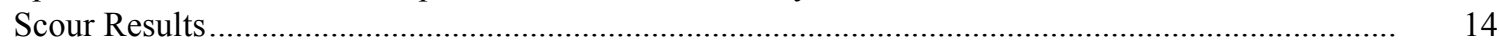

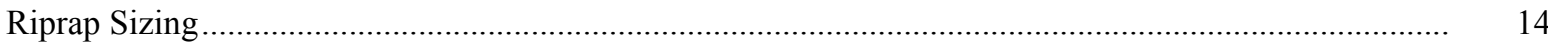

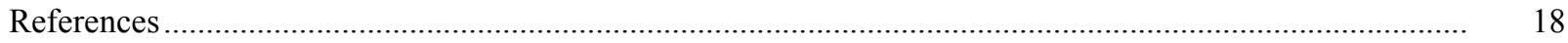

Appendixes:

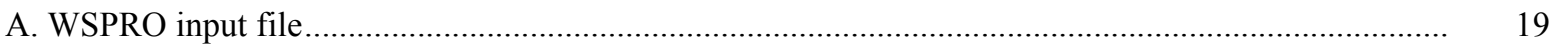

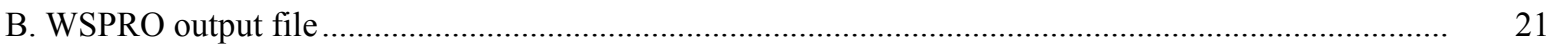

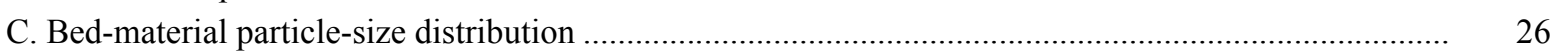

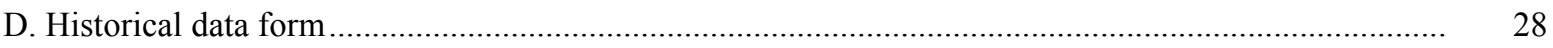

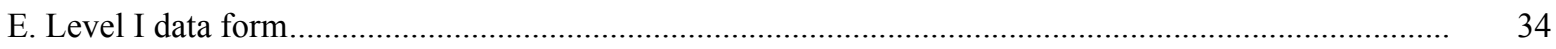

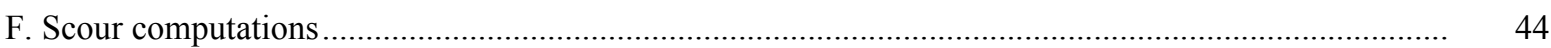

\section{FIGURES}

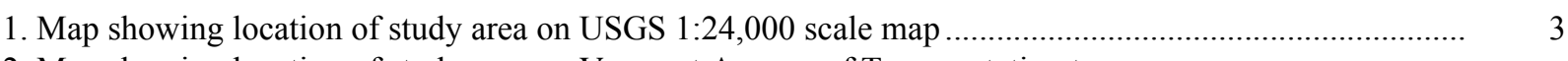

2. Map showing location of study area on Vermont Agency of Transportation town

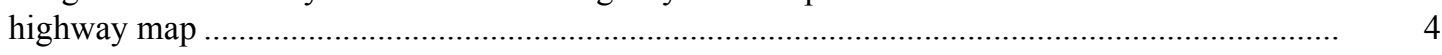

3. Structure BLOOVT01050096 viewed from upstream (July 6, 1995) .....................................................

4. Downstream channel viewed from structure BLOOVT01050096 (July 6, 1995) ................................ 5

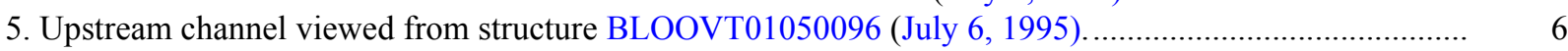

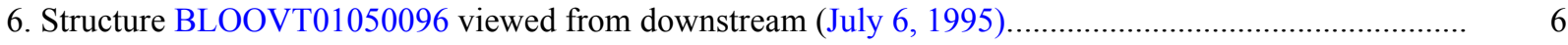

7. Water-surface profiles for the 100- and 500-year discharges at structure

BLOOVT01050096 on Vermont Route 105, crossing Nulhegan River,

Bloomfield, Vermont.

8. Scour elevations for the 100- and 500-year discharges at structure

BLOOVT01050096 on Vermont Route 105, crossing Nulhegan River,

Bloomfield, Vermont.

\section{TABLES}

1. Remaining footing/pile depth at abutments for the 100-year discharge at structure

BLOOVT01050096 on Vermont Route 105, crossing Nulhegan River,

Bloomfield, Vermont....

2. Remaining footing/pile depth at abutments for the 500-year discharge at structure

BLOOVT01050096 on Vermont Route 105, crossing Nulhegan River,

Bloomfield, Vermont

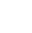




\begin{tabular}{|c|c|c|}
\hline Multiply & By & To obtain \\
\hline \multicolumn{3}{|c|}{ Length } \\
\hline inch (in.) & 25.4 & millimeter (mm) \\
\hline foot $(\mathrm{ft})$ & 0.3048 & $\operatorname{meter}(\mathrm{m})$ \\
\hline mile (mi) & 1.609 & kilometer (km) \\
\hline \multicolumn{3}{|c|}{ Slope } \\
\hline foot per mile ( $\mathrm{ft} / \mathrm{mi})$ & 0.1894 & meter per kilometer $(\mathrm{m} / \mathrm{km})$ \\
\hline \multicolumn{3}{|c|}{ Area } \\
\hline square mile $\left(\mathrm{mi}^{2}\right)$ & 2.590 & square kilometer $\left(\mathrm{km}^{2}\right)$ \\
\hline \multicolumn{3}{|c|}{ Volume } \\
\hline cubic foot $\left(\mathrm{ft}^{3}\right)$ & $\begin{array}{l}0.02832 \\
\text { Velocity and Flow }\end{array}$ & cubic meter $\left(\mathrm{m}^{3}\right)$ \\
\hline foot per second $(\mathrm{ft} / \mathrm{s})$ & 0.3048 & meter per second $(\mathrm{m} / \mathrm{s})$ \\
\hline cubic foot per second $\left(\mathrm{ft}^{3} / \mathrm{s}\right)$ & 0.02832 & cubic meter per second $\left(\mathrm{m}^{3} / \mathrm{s}\right)$ \\
\hline $\begin{array}{l}\text { cubic foot per second per } \\
\text { square mile } \\
{\left[\left(\mathrm{ft}^{3} / \mathrm{s}\right) / \mathrm{mi}^{2}\right]}\end{array}$ & 0.01093 & $\begin{array}{l}\text { cubic meter per } \\
\text { second per square } \\
\text { kilometer }\left[\left(\mathrm{m}^{3} / \mathrm{s}\right) / \mathrm{km}^{2}\right]\end{array}$ \\
\hline
\end{tabular}

OTHER ABBREVIATIONS

$\begin{array}{lrlr}\mathrm{BF} & \text { bank full } & \text { LWW } & \text { left wingwall } \\ \mathrm{cfs} & \text { cubic feet per second } & \text { MC } & \text { main channel } \\ \mathrm{D}_{50} & \text { median diameter of bed material } & \text { RAB } & \text { right abutment } \\ \mathrm{DS} & \text { downstream } & \text { RABUT } & \text { face of right abutment } \\ \mathrm{elev} & \text { elevation } & \text { RB } & \text { right bank } \\ \mathrm{f} / \mathrm{p} & \text { flood plain } & \text { ROB } & \text { right overbank } \\ \mathrm{ft} & \text { square feet } & \text { RWW } & \text { right wingwall } \\ \mathrm{ft} / \mathrm{ft} & \text { feet per foot } & \text { TH } & \text { town highway } \\ \mathrm{JCT} & \text { junction } & \text { UB } & \text { under bridge } \\ \mathrm{LAB} & \text { left abutment } & \text { US } & \text { upstream } \\ \mathrm{LABUT} & \text { face of left abutment } & \text { USGS } & \text { United States Geological Survey } \\ \text { LB } & \text { left bank } & \text { VTAOT Vermont Agency of Transportation } \\ \text { LOB } & \text { left overbank } & \text { WSPRO } & \text { water-surface profile model }\end{array}$

In this report, the words "right" and "left" refer to directions that would be reported by an observer facing downstream. Sea level: In this report, "sea level" refers to the National Geodetic Vertical Datum of 1929-- a geodetic datum derived from a general adjustment of the first-order level nets of the United States and Canada, formerly called Sea Level Datum of 1929.

In the appendices, the above abbreviations may be combined. For example, USLB would represent upstream left bank. 


\title{
LEVEL II SCOUR ANALYSIS FOR BRIDGE 96 (BLOOVT01050096) ON VERMONT ROUTE 105, CROSSING THE NULHEGAN RIVER, BLOOMFIELD, VERMONT
}

\author{
By Joseph D. Ayotte And Michael A. Ivanoff
}

\section{INTRODUCTION AND SUMMARY OF RESULTS}

This report provides the results of a detailed Level II analysis of scour potential at structure BLOOVT01050096 on Vermont Route 105 crossing the Nulhegan River, Bloomfield, Vermont (figures 1-8). A Level II study is a basic engineering analysis of the site, including a quantitative analysis of stream stability and scour (U.S. Department of Transportation, 1993). Results of a Level I scour investigation also are included in Appendix E of this report. A Level I investigation provides a qualitative geomorphic characterization of the study site. Information on the bridge, gleaned from Vermont Agency of Transportation (VTAOT) files, was compiled prior to conducting Level I and Level II analyses and is found in Appendix D.

The site is in the White Mountain section of the New England physiographic province of north-east Vermont in the town of Bloomfield. The $103-\mathrm{mi}^{2}$ drainage area is in a predominantly rural and forested basin. In the vicinity of the study site, the surface cover is shrub and brushland upstream. Downstream of the bridge, the surface cover is forest.

In the study area, the Nulhegan River has an incised, sinuous channel with a slope of approximately $0.015 \mathrm{ft} / \mathrm{ft}$, an average channel top width of $78 \mathrm{ft}$ and an average channel depth of $5 \mathrm{ft}$. The predominant channel bed material is cobble with a median grain size $\left(\mathrm{D}_{50}\right)$ of $133 \mathrm{~mm}(0.435 \mathrm{ft})$. About 100 feet upstream, the streambed and bank materials abruptly change predominantly to sand. The geomorphic assessment at the time of the Level I and Level II site visit on July 6, 1995, indicated that the upstream reach, which is experiencing channel scour and severe bank cutting into the alluvial channel boundaries, is not stable. The downstream reach is semi- to non-alluvial and is assessed as stable.

The Vermont Route 105 crossing of the Nulhegan River is a 74-ft-long, two-lane bridge consisting of one 71-foot steel stringer type superstructure with a concrete deck (Vermont Agency of Transportation, written communication, August 5, 1994). The bridge is supported by vertical, concrete abutments with wingwalls. The channel is skewed approximately 10 degrees to the opening while the opening-skew-to-roadway is 25 degrees. 
A scour hole $4.0 \mathrm{ft}$ deeper than the mean thalweg depth was observed along the upstream channel during the Level I assessment. Scour protection measures at the site consist of type2 stone fill (less than 24 inches diameter) along the entire base length of both abutments and all wingwalls. Additional details describing conditions at the site are included in the Level II Summary and Appendices D and $\mathrm{E}$.

Scour depths and rock rip-rap sizes were computed using the general guidelines described in Hydraulic Engineering Circular 18 (Richardson and others, 1995). Total scour at a highway crossing is comprised of three components: 1) long-term streambed degradation; 2) contraction scour (due to accelerated flow caused by a reduction in flow area at a bridge) and; 3) local scour (caused by accelerated flow around piers and abutments). Total scour is the sum of the three components. Equations are available to compute depths for contraction and local scour and a summary of the results of these computations follows.

Contraction scour for all modelled flows ranged from 0.5 to $1.1 \mathrm{ft}$. The worst-case contraction scour occurred at the 500-year discharge. Abutment scour ranged from 10.5 to $16.2 \mathrm{ft}$. The worst-case abutment scour also occurred at the 500-year discharge. Additional information on scour depths and depths to armoring are included in the section titled "Scour Results". Scoured-streambed elevations, based on the calculated scour depths, are presented in tables 1 and 2. A cross-section of the scour computed at the bridge is presented in figure 8. Scour depths were calculated assuming an infinite depth of erosive material and a homogeneous particle-size distribution.

It is generally accepted that the Froehlich equation (abutment scour) gives "excessively conservative estimates of scour depths" (Richardson and others, 1995, p. 47). Usually, computed scour depths are evaluated in combination with other information including (but not limited to) historical performance during flood events, the geomorphic stability assessment, existing scour protection measures, and the results of the hydraulic analyses. Therefore, scour depths adopted by VTAOT may differ from the computed values documented herein. 


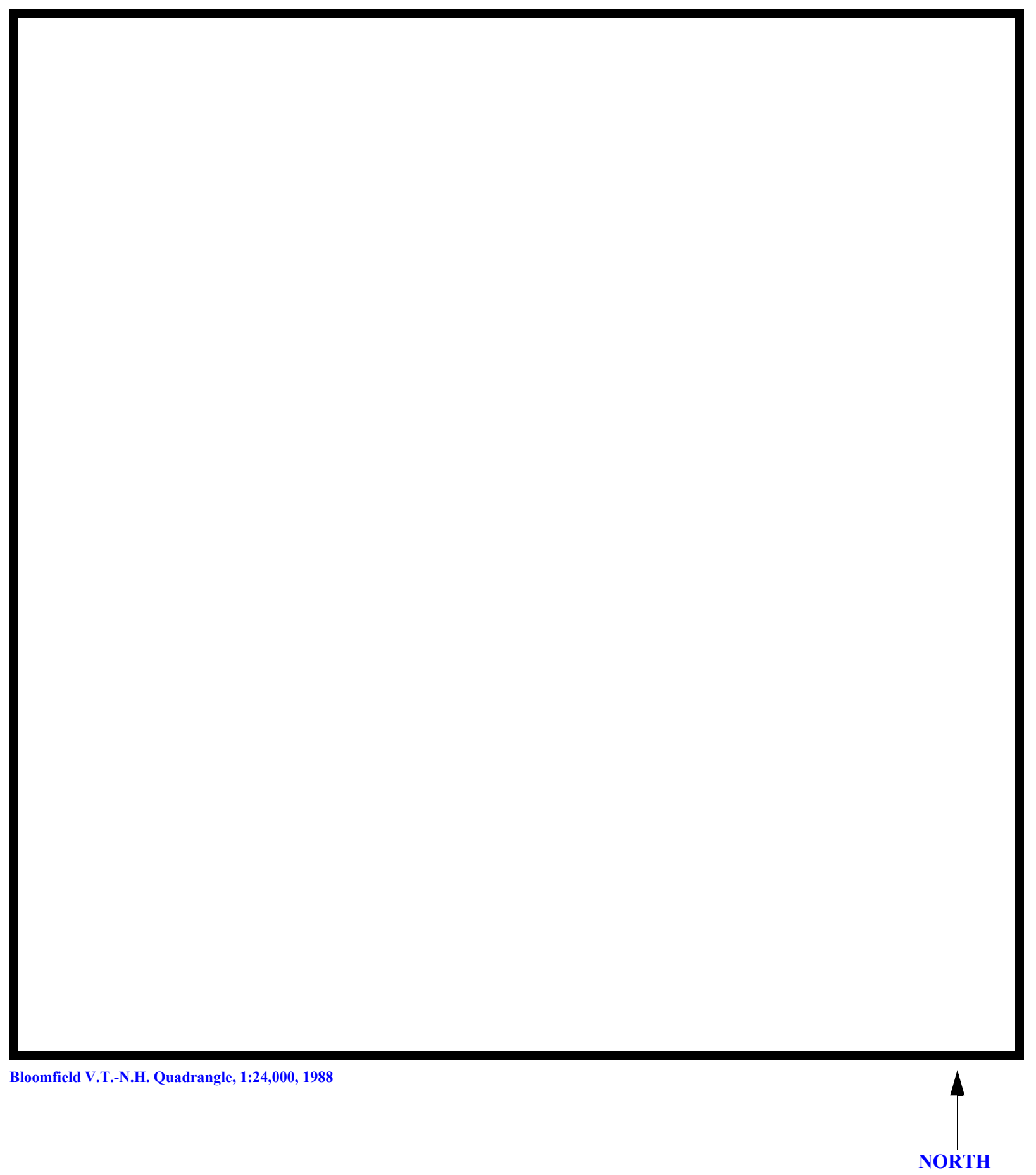

Figure 1. Location of study area on USGS 1:24,000 scale map. 
Figure 2. Location of study area on Vermont Agency of Transportation town highway map. 

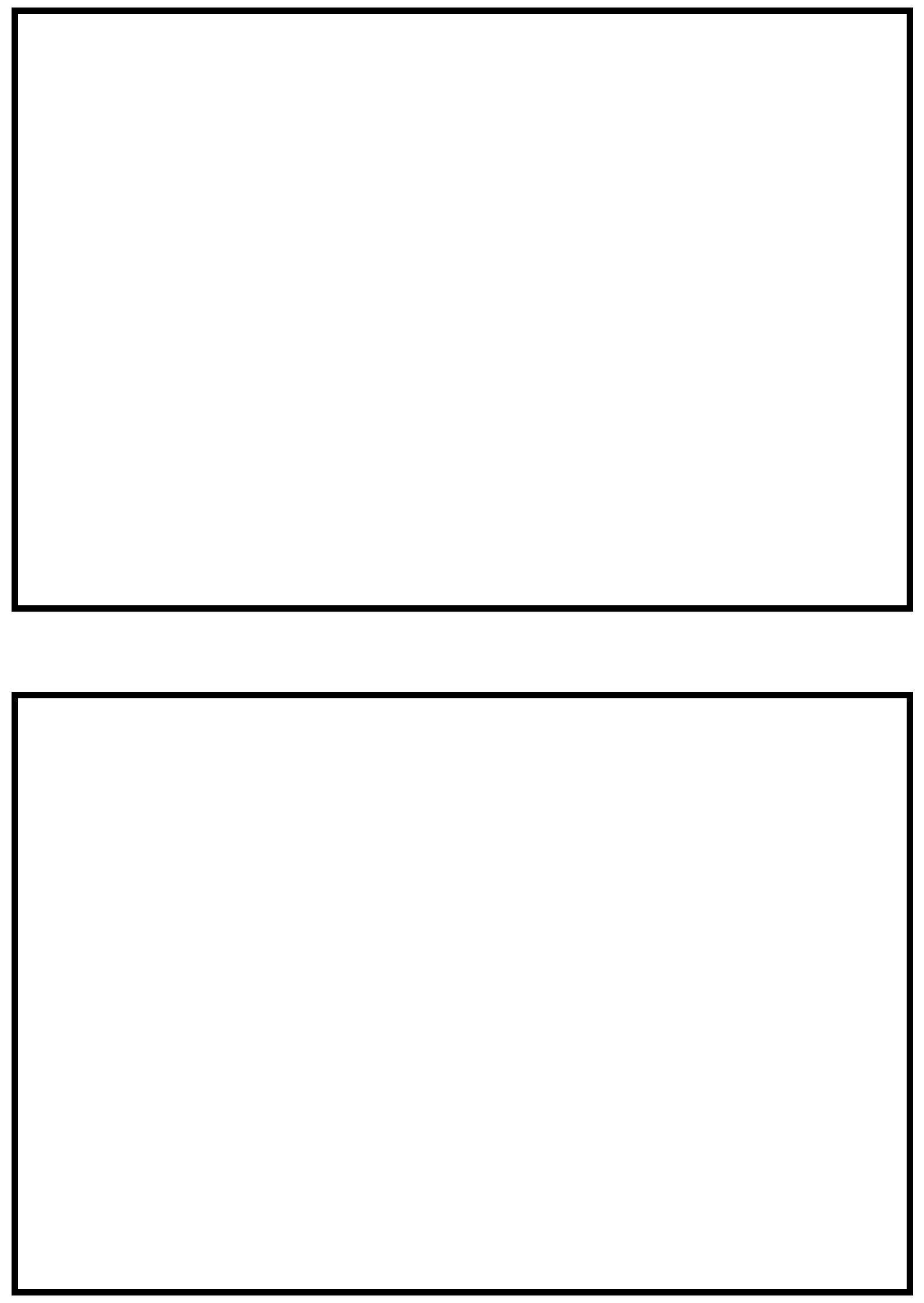

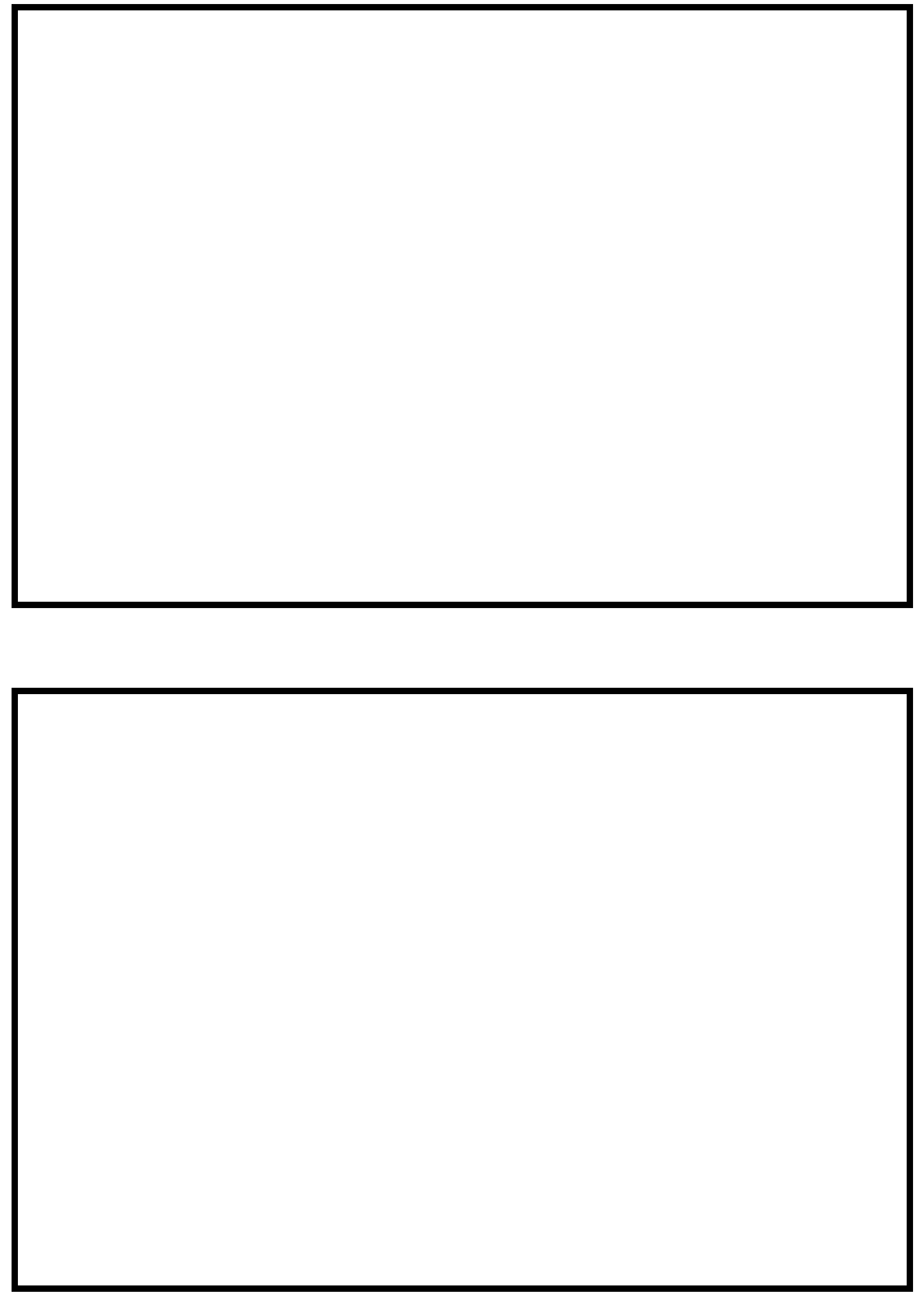


\section{LEVEL II SUMMARY}

\begin{tabular}{llllll} 
& Structure Number & BLOOVT01050096 & Stream & \multicolumn{2}{l}{ Nulhegan River } \\
& Essex & Road & VT105 & District & 9
\end{tabular}

\section{Description of Bridge}

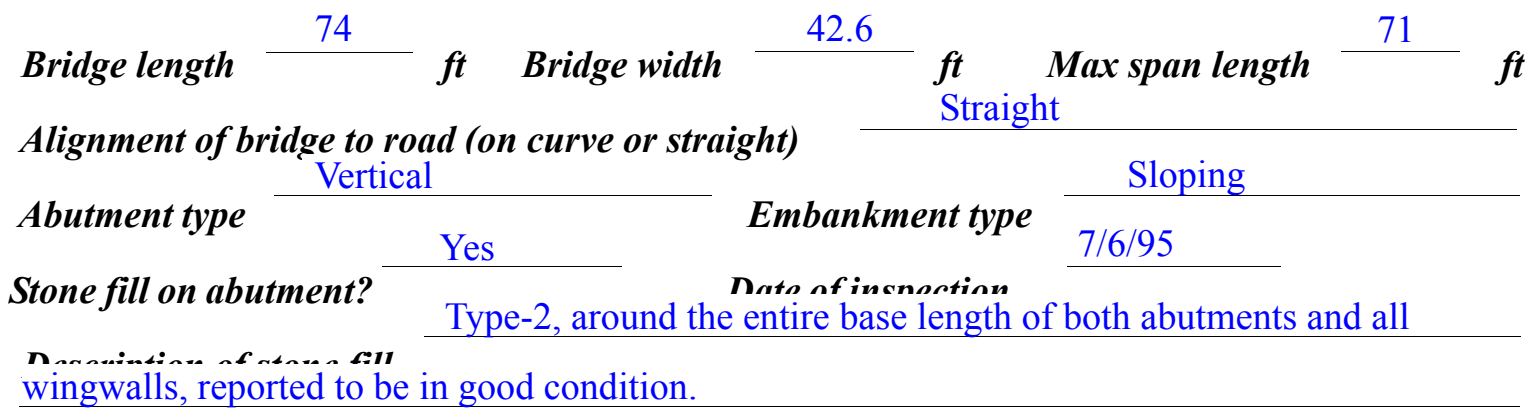

Abutments and wingwalls are concrete. There is a four foot deep scour hole approximately $125 \mathrm{ft}$ US of the bridge.

\section{$\mathrm{Y}$}

Is bridge skewed to flood flow according to Y Y survey?

Angle

There is a moderate channel bend in the downstream, reach

Debris accumulation on bridge at time of Level I or Level II site visit:

\begin{tabular}{|c|c|c|c|}
\hline & $\begin{array}{c}\text { Date of insnortion } \\
7 / 6 / 95 \\
\end{array}$ & $\begin{array}{l}\text { Percent of ofmonol } \\
\text { blocked inortzontatly }\end{array}$ & $\begin{array}{l}\text { Percent of } 0 \\
\text { blocked verticatty }\end{array}$ \\
\hline & $7 / 6 / 95$ & -- & -- \\
\hline
\end{tabular}

Level II

High. There is some debris in the channel upstream. Also,

historically, debris has been a problem.

Potential for debris

The US channel becomes significantly shallower than normal at a distance of less than one Doscriho anv, fonturos noar ar at tho hridoo that mav, affort flou, (includo ahsorvation dato) bridge length US-- 7/6/95. 


\section{Description of the Geomorphic Setting}

General topography The channel is located at the head of a natural constriction between two small mountains with steep valley walls. The valley is irregular in width elsewhere.

Geomorphic conditions at bridge site: downstream (DS), upstream (US)

Date of inspection $\quad 7 / 6 / 95$

DS left: $\quad$ Terraced overbank area (450 ft wide) to steep sloped valley wall

DS right: $\quad$ Narrow overbank area to moderately sloped valley wall

US left: $\quad$ Narrow overbank area to moderately sloped valley wall

US right: $\quad$ Sand and swamp overbank area to steep sloped valley wall

\section{Description of the Channel}

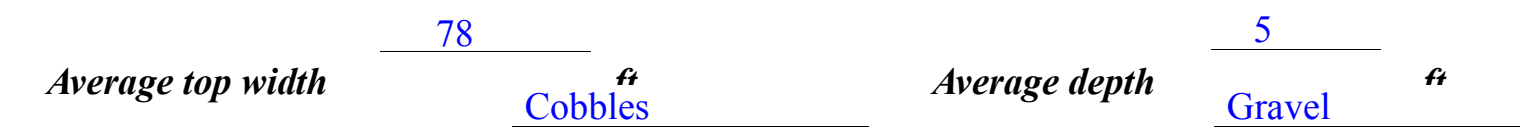

Predominant bed material

Bank material

Sinuous with

predominately alluvial channel boundaries and a variable-width floöd plain.

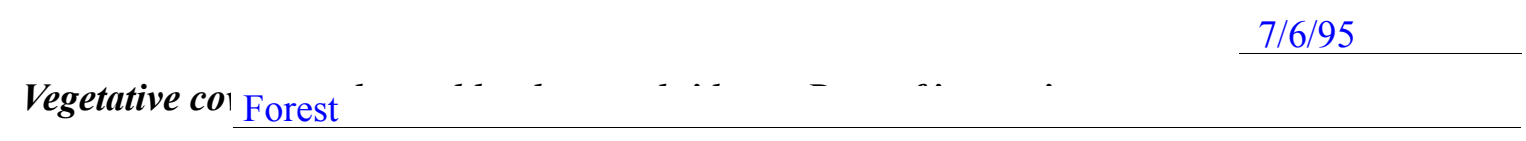

DS left: $\quad$ Forest

DS right: $\quad$ Shrub and brushland

US left: $\quad$ Shrub and brushland

US right: $\quad \underline{\mathrm{N}}$

Do banks appear stable? There is a major cut bank with block failure US on the RB and a cut date of observatton. with lesser amounts of erosion

The assessment of

7/6/95 noted flow conditions up to bank-full level are influenced boulders $100 \mathrm{ft}$ US of the Describe any obstructions in channel and date of observation.

bridge with scour in the channel closer to the bridge. 


\section{Hydrology}

Drainage area $\frac{103}{\boldsymbol{m i}^{2}}$

Percentage of drainage area in physiographic provinces: (approximate)

Physiographic province/section

New England / White Mountain
Percent of drainage area 100

Is drainage area considered rural or urban? Rural $\quad$ Describe any significant

urbanization: None

Is there a USGS gage on the stream of interest?

No

USGS gage description

USGS gage number

Gage drainage area $\mathrm{mi}^{2}$

No

Is there a lake/p

Q100 $\quad \mathrm{ft} / \mathrm{s} \quad \mathrm{Q500} \quad \mathrm{ft} / \mathrm{s}$

The 100- and 500-year discharges were the median

value of several_empirical estimation methods applicable to this basin's size and region, some of which were graphically extrapolated (Benson, 1962; Johnson and Tasker, 1974; FHWA, 1983;

Potter, 1957a\&b; Talbot, 1887). 


\section{Description of the Water-Surface Profile Model (WSPRO) Analysis}

Datum for WSPRO analysis (USGS survey, sea level, VTAOT plans)

USGS datum

Datum tie between USGS survey and VTAOT plans

Subtract 0.05 from USGS survey

to obtain VTAOT plans datum and sea level.

\section{Description of reference marks used to determine USGS datum.}

$\mathrm{RM} 1$ is the end of a spike in a pole $125 \mathrm{ft}$ from right abutment on the DS right road approach embankment (elev. $1050.94 \mathrm{ft}$, arbitrary datum). RM2 is the center of the triangle of a brass tablet at the junction of the DS right abutment and DS right wingwall (elev. $1050.30 \mathrm{ft}$, arbitrary datum).

\section{Cross-Sections Used in WSPRO Analysis}

\begin{tabular}{cccl}
\hline${ }^{1}$ Cross-section & $\begin{array}{c}\text { Section } \\
\text { Reference } \\
\text { Distance } \\
\text { (SRD) in feet }\end{array}$ & $\begin{array}{c}{ }^{2} \text { Cross-section } \\
\text { development }\end{array}$ & \multicolumn{1}{c}{ Comments } \\
\hline EXITX & -96 & 1 & Exit section \\
FULLV & 0 & 2 & $\begin{array}{l}\text { Downstream Full-valley } \\
\text { section (Templated from } \\
\text { EXITX) }\end{array}$ \\
BRIDG & 0 & 1 & $\begin{array}{l}\text { Bridge section (data from } \\
\text { US face) }\end{array}$ \\
RDWAY & 22 & 1 & $\begin{array}{l}\text { Road Grade section } \\
\text { Approach section (Sur- } \\
\text { APPRO }\end{array}$ \\
& 113 & 2 & $\begin{array}{l}\text { veyed at SRD of 82. No } \\
\text { shift of elevation data } \\
\text { required.) }\end{array}$ \\
\hline
\end{tabular}

${ }^{1}$ For location of cross-sections see plan-view sketch included with Level I field form, Appendix E. For more detail on how cross-sections were developed see WSPRO input file. 


\section{Data and Assumptions Used in WSPRO Model}

Hydraulic analyses of the reach were done by use of the Federal Highway Administration's WSPRO step-backwater computer program (Shearman and others, 1986, and Shearman, 1990). The analyses reported herein reflect conditions existing at the site at the time of the study. Furthermore, in the development of the model it was necessary to assume no accumulation of debris or ice at the site. Results of the hydraulic model are presented in the Bridge Hydraulic Summary, Appendix B, and figure 7.

Channel roughness factors (Manning's " $n$ ") used in the hydraulic model were estimated using field inspections at each cross section following the general guidelines described by Arcement and Schneider (1989). Final adjustments to the values were made during the modelling of the reach. Channel " $\mathrm{n}$ " values for the reach ranged from 0.040 to 0.060 , and overbank " $\mathrm{n}$ " values ranged from 0.040 to 0.100 .

Normal depth at the exit section (EXITX) was assumed as the starting water surface. This depth was computed by use of the slope-conveyance method outlined in the user's manual for WSPRO (Shearman, 1990). The slope used was $0.0154 \mathrm{ft} / \mathrm{ft}$ which was estimated from the topographic map (U.S. Geological Survey, 1988).

The surveyed approach section was moved to establish the modelled approach section (APPRO), one bridge length upstream of the upstream face as recommended by Shearman and others (1986). This approach also provides a consistent method for determining scour variables. Upstream of the surveyed approach section, which had a station reference distance (SRD) of 82, the channel became deeper. Thus an adjustment for slope was not made when the SRD was changed to 113 .

For the 100- and 500-year discharges, WSPRO assumes critical depth at the bridge section. Supercritical models were developed for these discharges. Analyzing both the supercritical and subcritical profiles for each discharge, it was determined that the water surface

profiles passed through critical depth within the bridge opening. Thus, the assumptions of critical depth at the bridge are satisfactory solutions. 


\section{Bridge Hydraulics Summary}

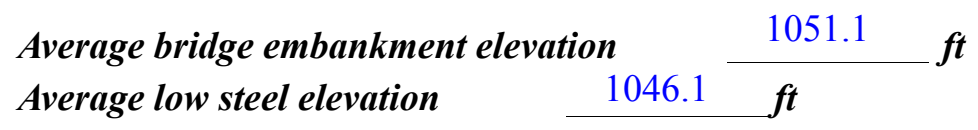

\begin{tabular}{|c|c|c|c|c|}
\hline \multirow{2}{*}{\multicolumn{3}{|c|}{$\begin{array}{l}\text { 100-year discharge } \\
\text { Water-surface elevation in bridge opening }\end{array}$}} & \multirow{3}{*}{\multicolumn{2}{|c|}{$1041.3 \mathrm{ft}$}} \\
\hline & & & & \\
\hline Road overtopping? & $\mathrm{N}$ & \multicolumn{2}{|c|}{ Discharge over road } & \\
\hline \multirow{3}{*}{\multicolumn{2}{|c|}{$\begin{array}{l}\text { Area of flow in bridge opening } \\
\text { Average velocity in bridge opening } \\
\text { Maximum WSPRO tube velocity at }\end{array}$}} & $368 \mathrm{ft}^{2}$ & & \\
\hline & & 13.9 & $f t / s$ & \\
\hline & & at bridge & 16.4 & $\mathrm{t} / \mathrm{s}$ \\
\hline
\end{tabular}

Water-surface elevation at Approach section with bridge Water-surface elevation at Approach section without bridge

1044.8 Amount of backwater caused by bridge

1.9 it

500-year discharge $\quad 7,000 \quad \mathrm{ft}^{3} / \mathrm{s}$

Water-surface elevation in bridge opening $1042.8 f t$

Road overtopping? ___ N Discharge over road $0, \ldots / s$

Area of flow in bridge opening

Average velocity in bridge opening $455 \quad \boldsymbol{f t}^{2}$

Maximum WSPRO tube velocity at bridge 18.3 , 's

Water-surface elevation at Approach section with bridge

Water-surface elevation at Approach section without bridge

1046.7

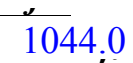

Amount of backwater caused by bridge

2.7 .

Incipient overtopping discharge ___ -- $f t^{3} / s$

Water-surface elevation in bridge opening $\quad--\quad$ it

Area of flow in bridge opening $-{ }_{-} t^{2}$

Average velocity in bridge opening

Maximum WSPRO tube velocity at bridge

$-f^{-} \mathrm{ft} / \mathrm{s}$

$-f^{-} f t / s$

Water-surface elevation at Approach section with bridge

Water-surface elevation at Approach section without bridge

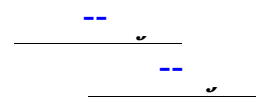
Amount of backwater caused by bridge $-\quad i$ 


\section{Scour Analysis Summary}

\section{Special Conditions or Assumptions Made in Scour Analysis}

Scour depths were computed using the general guidelines described in Hydraulic Engineering Circular 18 (Richardson and others, 1995). Scour depths were calculated assuming an infinite depth of erosive material and a homogeneous particle-size distribution. The results of the scour analysis are presented in tables 1 and 2 and a graph of the scour depths is presented in figure 8 .

About 100 feet upstream of bridge 96 in Bloomfield, the bed material is primarily sand. Samples taken of the the sand had a median grain size of about $0.80 \mathrm{~mm}$. Using this material size, live-bed conditions would control scour. However, the channel is cobble through the bridge opening to about 75 feet upstream. Using the median grain size of this coarse material, $133 \mathrm{~mm}$, clear-water conditions would control scour. Since the coarse material size best represents the bed under the structure, contraction scour was computed by use of the clear-water contraction scour equation (Richardson and others, 1995, p. 32, equation 20). For contraction scour computations, the average depth in the contracted section (AREA/TOPWIDTH) is subtracted from the depth of flow computed by the scour equation (Y2) to determine the actual amount of scour. Streambed armoring depths computed suggest that the depths of contraction scour will not be limited by armoring

Abutment scour for the both abutments at all modelled discharges was computed by use of the Froehlich equation (Richardson and others, 1995, p. 48, equation 28). Variables for the Froehlich equation include the Froude number of the flow approaching the embankments, the length of the embankment blocking flow, and the depth of flow approaching the embankment less any roadway overtopping. 


\section{Scour Results}

100-yr discharge 500-yrdischarge

Incipient

Contraction scour:

(Scour depths in feet)

Main channel

Live-bed scour
Clear-water scour
Depth to armoring
bank
erbank

Right overbank

Local scour:

Abutment scour

Left abutment

14.5

16.2

10.5

$11.3-$

\section{Right abutment}

Pier scour

Pier 1

Pier 2

Pier 3

Abutments:

Left abutment

Right abutment

Piers:

Pier 1

Pier 2

\section{Riprap Sizing}

overtopping

discharge

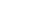




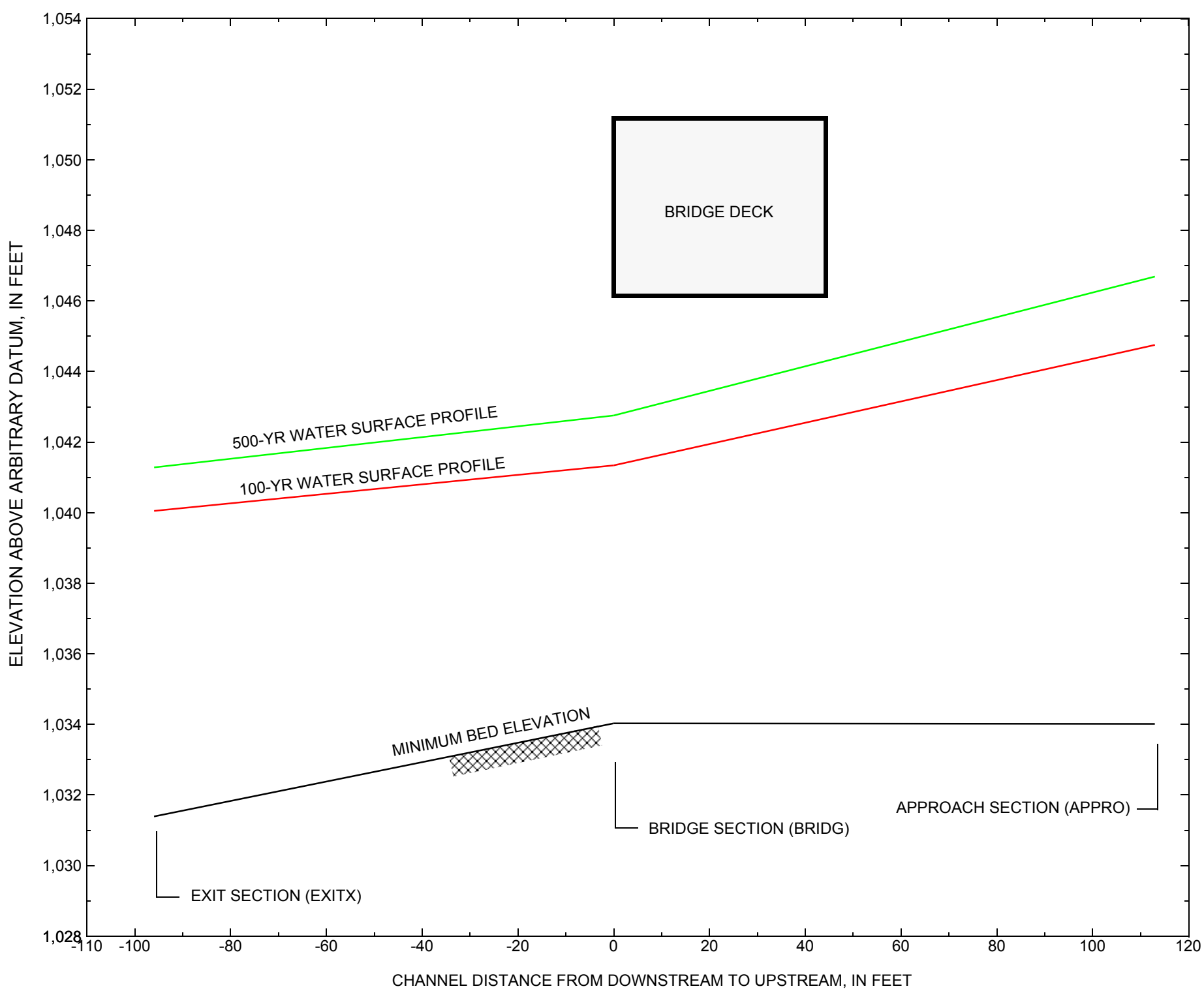

Figure 7. Water-surface profiles for the 100- and 500-yr discharges at structure BLOOVT01050096 on Vermont Route 105, crossing Nulhegan River, Bloomfield, Vermont. 


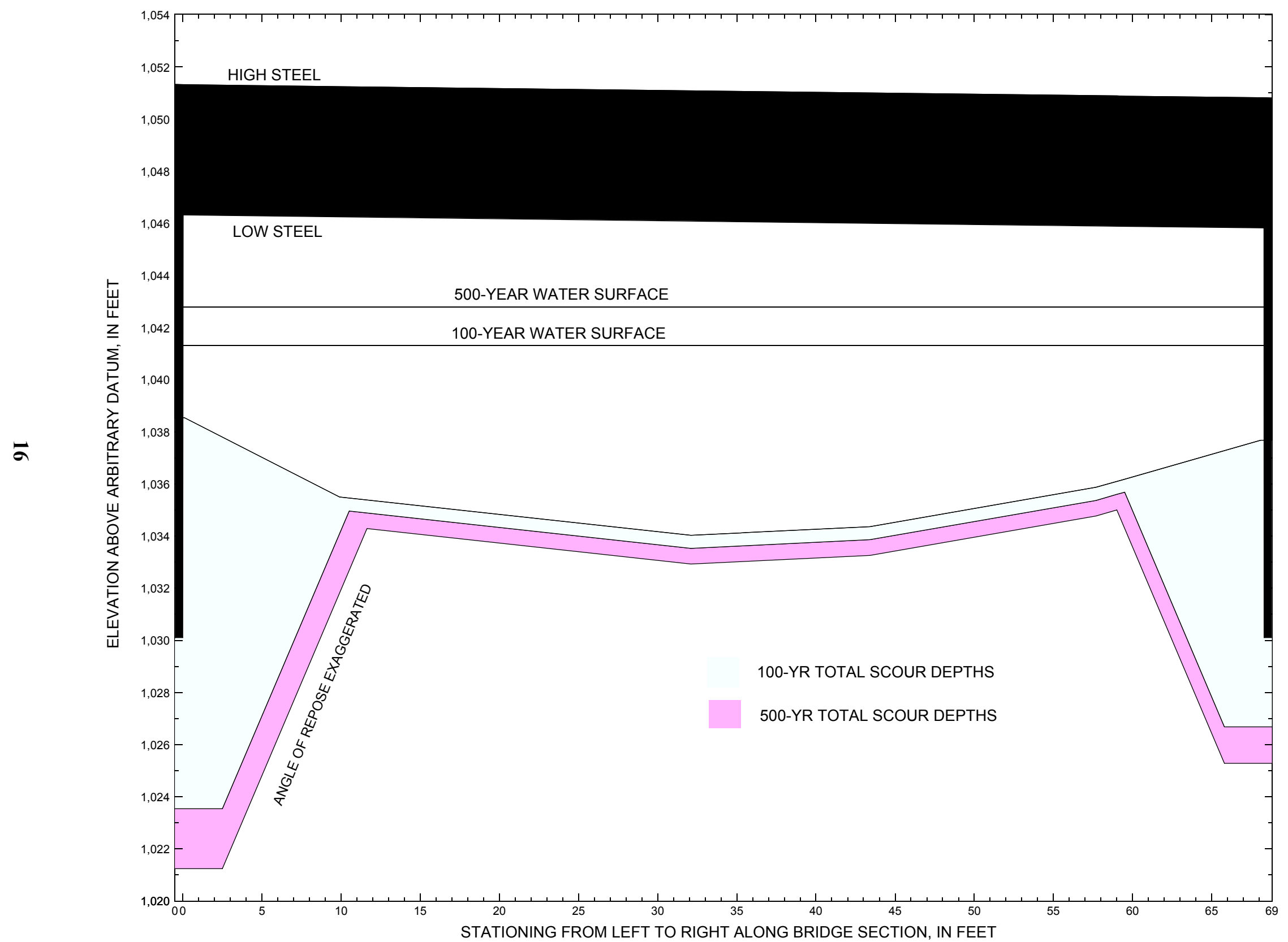

Figure 8. Scour elevations for the 100-yr and 500-yr discharges at structure BLOOVT01050096 on Vermont Route 105, crossing Nulhegan River, Bloomfield, Vermont. 
Table 1. Remaining footing/pile depth at abutments for the 100-year discharge at structure BLOOVT01050096 on Vermont Route 105, crossing Nulhegan River, Bloomfield, Vermont.

[VTAOT, Vermont Agency of Transportation; --,no data]

\begin{tabular}{|c|c|c|c|c|c|c|c|c|c|c|c|}
\hline Description & Station $^{1}$ & $\begin{array}{l}\text { VTAOT } \\
\text { minimum } \\
\text { low-chord } \\
\text { elevation } \\
\text { (feet) }\end{array}$ & $\begin{array}{c}\text { Surveyed } \\
\text { minimum } \\
\text { low-chord } \\
\text { elevation } \\
\text { (feet) }\end{array}$ & $\begin{array}{l}\text { Bottom of } \\
\text { footing } \\
\text { elevation } \\
\text { (feet) }\end{array}$ & $\begin{array}{c}\text { Channel } \\
\text { elevation at } \\
\text { abutment/ } \\
\text { pier }^{2} \\
\text { (feet) }\end{array}$ & $\begin{array}{l}\text { Contraction } \\
\text { scour depth } \\
\text { (feet) }\end{array}$ & $\begin{array}{l}\text { Abutment } \\
\text { scour } \\
\text { depth } \\
\text { (feet) }\end{array}$ & $\begin{array}{l}\text { Pier } \\
\text { scour } \\
\text { depth } \\
\text { (feet) }\end{array}$ & $\begin{array}{l}\text { Depth of } \\
\text { total scour } \\
\text { (feet) }\end{array}$ & $\begin{array}{l}\text { Elevation of } \\
\text { scour }^{2} \\
\text { (feet) }\end{array}$ & $\begin{array}{c}\text { Remaining } \\
\text { footing/pile } \\
\text { depth } \\
\text { (feet) }\end{array}$ \\
\hline \multicolumn{12}{|c|}{100 -yr. discharge is 5,100 cubic-feet per second } \\
\hline Left abutment & 0.0 & 1046.26 & 1046.31 & 1030.1 & 1038.5 & 0.5 & 14.5 & -- & 15.0 & 1023.5 & -6.6 \\
\hline Right abutment & 68.3 & 1045.80 & 1045.85 & 1030.1 & 1037.7 & 0.5 & 10.5 & -- & 11.0 & 1026.7 & -3.4 \\
\hline
\end{tabular}

${ }^{1 .}$ Measured along the face of the most constricting side of the bridge.

2. Arbitrary datum for this study.

Table 2. Remaining footing/pile depth at abutments for the 500-year discharge at structure BLOOVT01050096 on Vermont Route 105, crossing Nulhegan River, Bloomfield, Vermont.

[VTAOT, Vermont Agency of Transportation; --, no data]

\begin{tabular}{|c|c|c|c|c|c|c|c|c|c|c|c|}
\hline Description & Station $^{1}$ & $\begin{array}{l}\text { VTAOT } \\
\text { minimum } \\
\text { low-chord } \\
\text { elevation } \\
\text { (feet) }\end{array}$ & $\begin{array}{l}\text { Surveyed } \\
\text { minimum } \\
\text { low-chord } \\
\text { elevation } \\
\text { (feet) }\end{array}$ & $\begin{array}{l}\text { Bottom of } \\
\text { footing } \\
\text { elevation } \\
\text { (feet) }\end{array}$ & $\begin{array}{c}\text { Channel } \\
\text { elevation at } \\
\text { abutment/ } \\
\text { pier }^{2} \\
\text { (feet) }\end{array}$ & $\begin{array}{l}\text { Contraction } \\
\text { scour depth } \\
\text { (feet) }\end{array}$ & $\begin{array}{l}\text { Abutment } \\
\text { scour } \\
\text { depth } \\
\text { (feet) }\end{array}$ & $\begin{array}{l}\text { Pier } \\
\text { scour } \\
\text { depth } \\
\text { (feet) }\end{array}$ & $\begin{array}{l}\text { Depth of } \\
\text { total scour } \\
\text { (feet) }\end{array}$ & $\begin{array}{c}\text { Elevation of } \\
\text { scour }^{2} \\
\text { (feet) }\end{array}$ & $\begin{array}{c}\text { Remaining } \\
\text { footing/pile } \\
\text { depth } \\
\text { (feet) }\end{array}$ \\
\hline \multicolumn{12}{|c|}{500 -yr. discharge is 7,000 cubic-feet per second } \\
\hline Left abutment & 0.0 & 1046.26 & 1046.31 & 1030.1 & 1038.5 & 1.1 & 16.2 & -- & 17.3 & 1021.2 & -8.9 \\
\hline Right abutment & 68.3 & 1045.80 & 1045.85 & 1030.1 & 1037.7 & 1.1 & 11.3 & -- & 12.4 & 1025.3 & -4.8 \\
\hline
\end{tabular}

1. Measured along the face of the most constricting side of the bridge.

2. Arbitrary datum for this study. 


\section{SELECTED REFERENCES}

Arcement, G.J., Jr., and Schneider, V.R., 1989, Guide for selecting Manning's roughness coefficients for natural channels and flood plains: U.S. Geological Survey Water-Supply Paper 2339, 38 p.

Barnes, H.H., Jr., 1967, Roughness characteristics of natural channels: U.S. Geological Survey Water-Supply Paper 1849, 213 p.

Benson, M.A., 1962, Factors influencing the occurrence of floods in a humid region of diverse terrain: U.S. Geological Survey WaterSupply Paper 1580-B, 64 p.

Brown, S.A. and Clyde, E.S., 1989, Design of riprap revetment: Federal Highway Administration Hydraulic Engineering Circular No. 11, Publication FHWA-IP-89-016, 156 p.

Federal Highway Administration, 1983, Runoff estimates for small watersheds and development of sound design: Federal Highway Administration Report FHWA-RD-77-158

Froehlich, D.C., 1989, Local scour at bridge abutments in Ports, M.A., ed., Hydraulic Engineering--Proceedings of the 1989 National Conference on Hydraulic Engineering: New York, American Society of Civil Engineers, p. 13-18.

Hayes, D.C.,1993, Site selection and collection of bridge-scour data in Delaware, Maryland, and Virginia: U.S. Geological Survey Water-Resources Investigation Report 93-4017, 23 p.

Johnson, C.G. and Tasker, G.D.,1974, Progress report on flood magnitude and frequency of Vermont streams: U.S. Geological Survey Open-File Report 74-130, 37 p.

Lagasse, P.F., Schall, J.D., Johnson, F., Richardson, E.V., Chang, F., 1995, Stream Stability at Highway Structures: Federal Highway Administration Hydraulic Engineering Circular No. 20, Publication FHWA-IP-90-014, 144 p.

Laursen, E.M., 1960, Scour at bridge crossings: Journal of the Hydraulics Division, American Society of Civil Engineers, v. 86, no. HY2, p. 39-53.

Potter, W. D., 1957a, Peak rates of runoff in the Adirondack, White Mountains, and Maine woods area, Bureau of Public Roads

Potter, W. D., 1957b, Peak rates of runoff in the New England Hill and Lowland area, Bureau of Public Roads

Richardson, E.V. and Davis, S.R., 1995, Evaluating scour at bridges: Federal Highway Administration Hydraulic Engineering Circular No. 18, Publication FHWA-IP-90-017, 204 p.

Richardson, E.V., Simons, D.B., and Julien, P.Y., 1990, Highways in the river environment: Federal Highway Administration Publication FHWA-HI-90-016.

Ritter, D.F., 1984, Process Geomorphology: W.C. Brown Co., Debuque, Iowa, 603 p.

Shearman, J.O., 1990, User's manual for WSPRO--a computer model for water surface profile computations: Federal Highway Administration Publication FHWA-IP-89-027, 187 p.

Shearman, J.O., Kirby, W.H., Schneider, V.R., and Flippo, H.N., 1986, Bridge waterways analysis model; research report: Federal Highway Administration Publication FHWA-RD-86-108, 112 .

Talbot, A.N., 1887, The determination of water-way for bridges and culverts.

U.S. Department of Transportation, 1993, Stream stability and scour at highway bridges, Participant Workbook: Federal Highway Administration Publication FHWA HI-91-011.

U.S. Geological Survey, 1988, Bloomfield, Vermont-New Hampshire 7.5 Minute Series quadrangle map: U.S. Geological Survey Topographic Maps, Scale 1:24,000. 


\section{APPENDIX A: \\ WSPRO INPUT FILE}




\section{WSPRO INPUT FILE}

GR

GR

GR

GR

GR

GR

GR

$\mathrm{N}$

$\mathrm{SA}$

XS

*

BR

GR

GR

GR

$\mathrm{N}$

CD

$\mathrm{XR}$

GR

GR

AS

GR

GR

GR

GR

GR

$\mathrm{N}$

SA

\section{*}

HP 1 BRIDG

HP 2 BRIDG

$\mathrm{HP} 1 \mathrm{APPRO}$

HP 2 APPRO

*

HP 1 BRIDG

HP 2 BRIDG

$\mathrm{HP} 1 \mathrm{APPRO}$

HP 2 APPRO

*

EX
U.S. Geological Survey WSPRO Input File bloo096.wsp Hydraulic analysis for structure BLOOVT01050096 Date: 17-APR-96 Bloomfield br 96, Vt Rte 102 crossing Nulhegan R.

JDA 51007000

$0.0154 \quad 0.0154$

$\begin{array}{lllllllllllllllllllll}6 & 29 & 30 & 552 & 553 & 551 & 5 & 16 & 17 & 13 & 3 & * & 15 & 14 & 23 & 21 & 11 & 12 & 4 & 7 & 3\end{array}$

EXITX $\quad-96$

$\begin{array}{rrr}-376.9,1070.25 & -343.3,1057.53 & -142.8,1051.38 \\ -62.1,1045.71 & -26.4,1045.48 & -17.2,1039.97 \\ 0.0,1034.12 & 8.3,1032.68 & 15.5,1032.90 \\ 38.3,1032.24 & 45.8,1033.80 & 49.9,1035.01 \\ 101.9,1038.33 & 126.8,1043.05 & 146.1,1044.09 \\ 205.9,1050.25 & 216.4,1045.73 & 229.6,1048.45 \\ 250.1,1047.50 & 256.1,1046.79 & 258.1,1045.57 \\ 266.3,1047.48 & 287.8,1049.11 & 312.7,1058.95 \\ 0.050 & 0.060 & 0.100\end{array}$

$-67.4,1045.14$

$-12.2,1035.39$

$21.1,1031.39$

$57.0,1037.88$

$187.8,1050.10$

$242.1,1048.97$

$262.2,1045.59$

$9.9,1035.50$

$32.1,1034.03$

$68.1,1037.68$

$68.3,1045.85$

$43.4,1034.36$

$57.7,1035.87$

$0.0,1046.31$

0.040

158.4 * * 3213

$0.0,1051.41$

$72.1,1050.74$

$636.7,1054.81$

$-14.5,1041.92$

$23.5,1034.04$

$67.5,1041.34$

$226.2,1048.29$

$526.5,1052.04$ 


\section{APPENDIX B: \\ WSPRO OUTPUT FILE}


WSPRO OUTPUT FILE

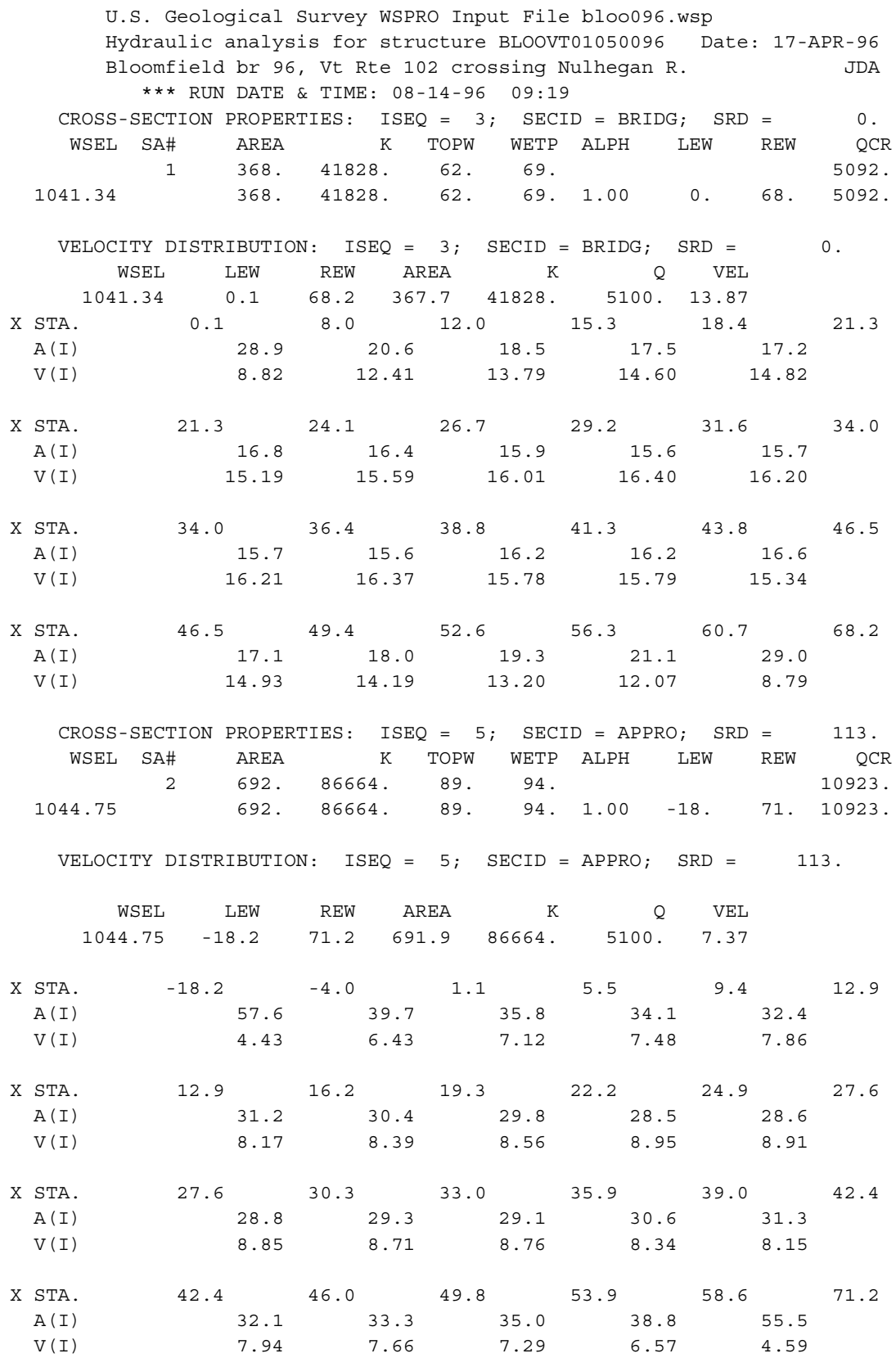


WSPRO OUTPUT FILE (continued)

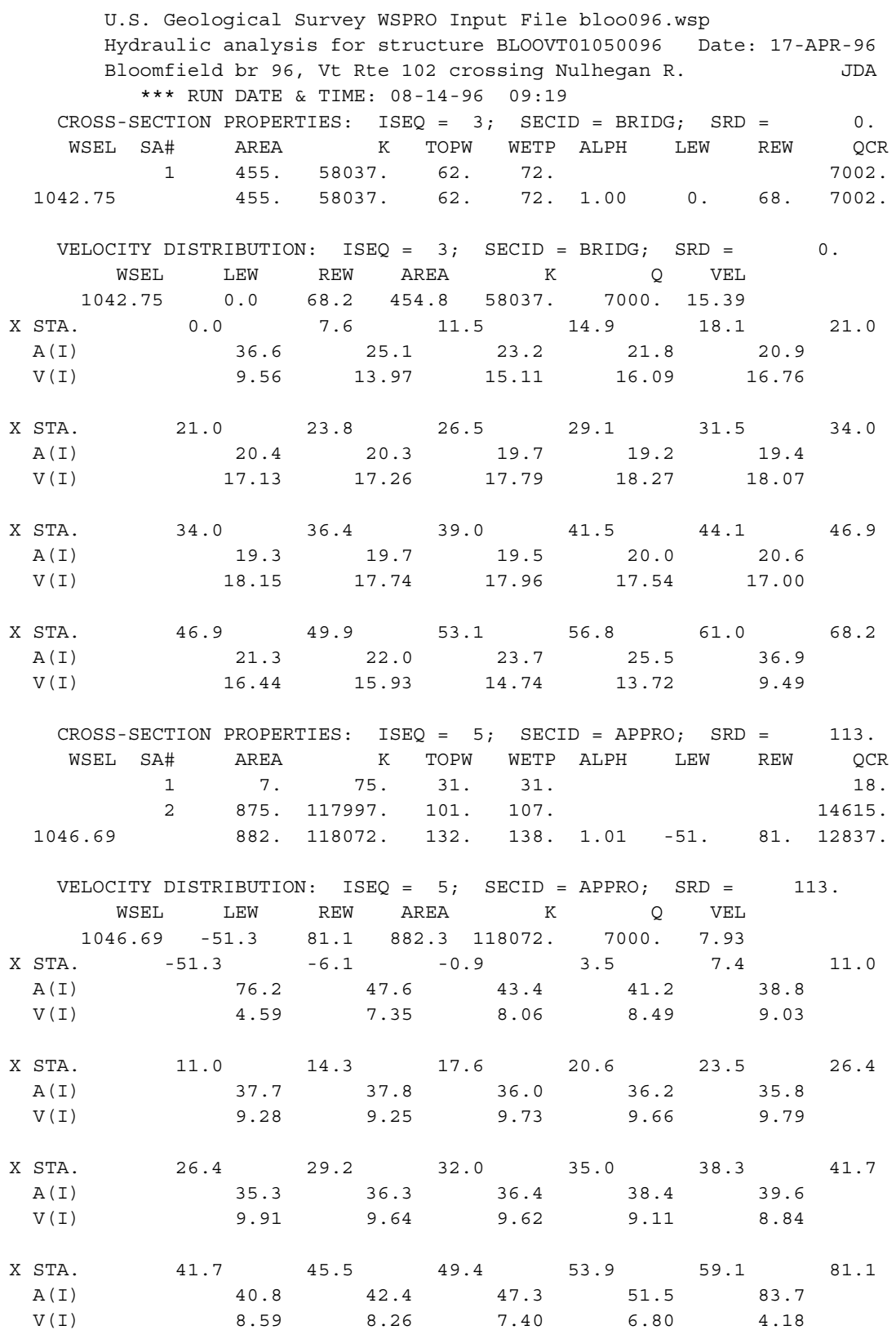


WSPRO OUTPUT FILE (continued)

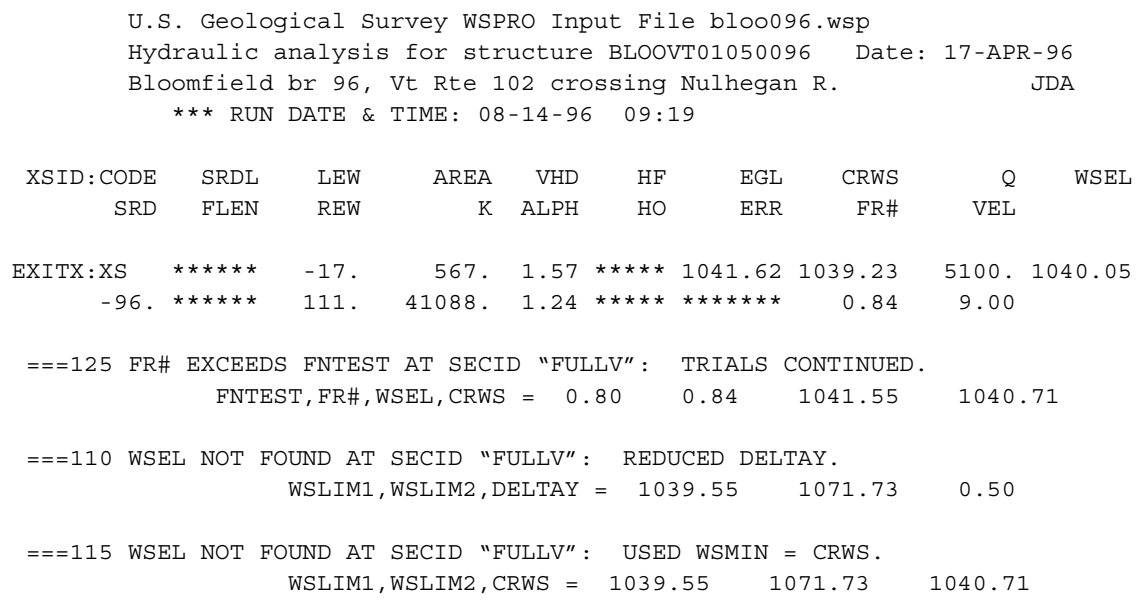


WSPRO OUTPUT FILE (continued)

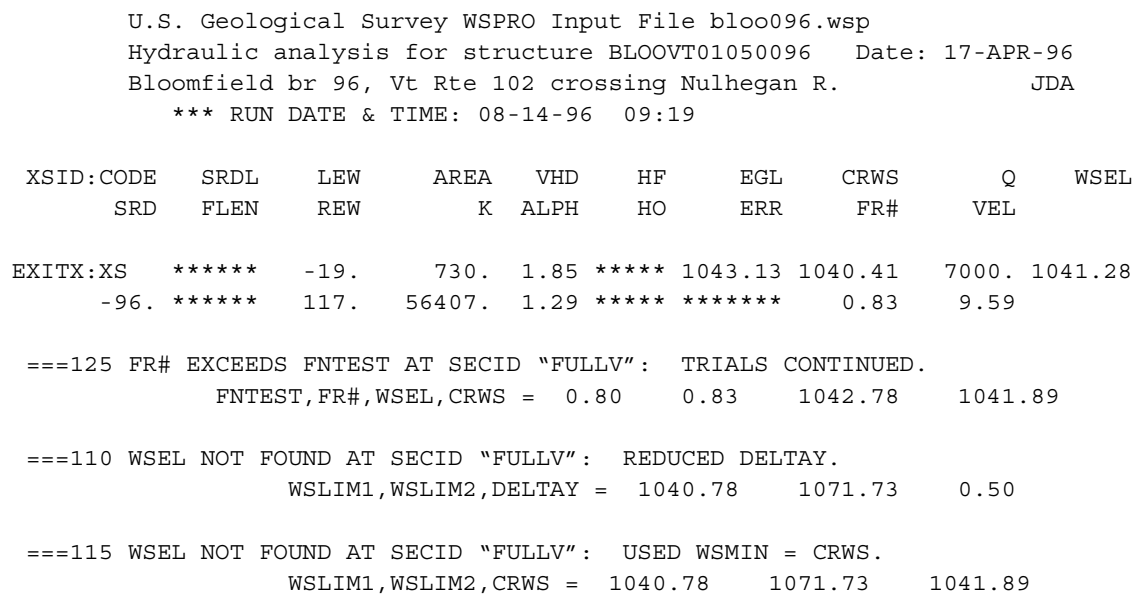

SECOND USER DEFINED TABLE.

\begin{tabular}{|c|c|c|c|c|c|c|c|c|c|}
\hline XSID : CODE & CRWS & FR\# & YMIN & YMAX & $\mathrm{HF}$ & HO & VHD & EGL & WSEL \\
\hline EXITX:XS & 1040.41 & 0.83 & 1031.39 & $1070.25 *$ & $\approx * \star * \pi$ & *** & 1.85 & 1043.13 & 1041.28 \\
\hline FULLV: FV & 1041.89 & 0.83 & 1032.87 & 1071.73 & 1.48 & 0.00 & 1.84 & 1044.61 & 1042.77 \\
\hline BRIDG : BR & 1042.75 & 1.00 & 1034.03 & $1046.31 *$ & $* * * * *$ & $* * * *$ & 3.68 & 1046.43 & 1042.75 \\
\hline WAY: RG & 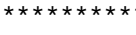 & 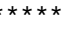 & 1050.74 & $1061.59 *$ & 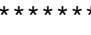 & 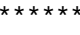 & 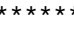 & 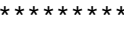 & $\sin ^{2}$ \\
\hline PRO : AS & 1042.60 & 0.55 & 1034.01 & 1059.72 & 0.40 & 0.85 & 0.99 & 1047.68 & 1046.69 \\
\hline
\end{tabular}




\section{APPENDIX C:}

\section{BED-MATERIAL PARTICAL-SIZE DISTRIBUTION}




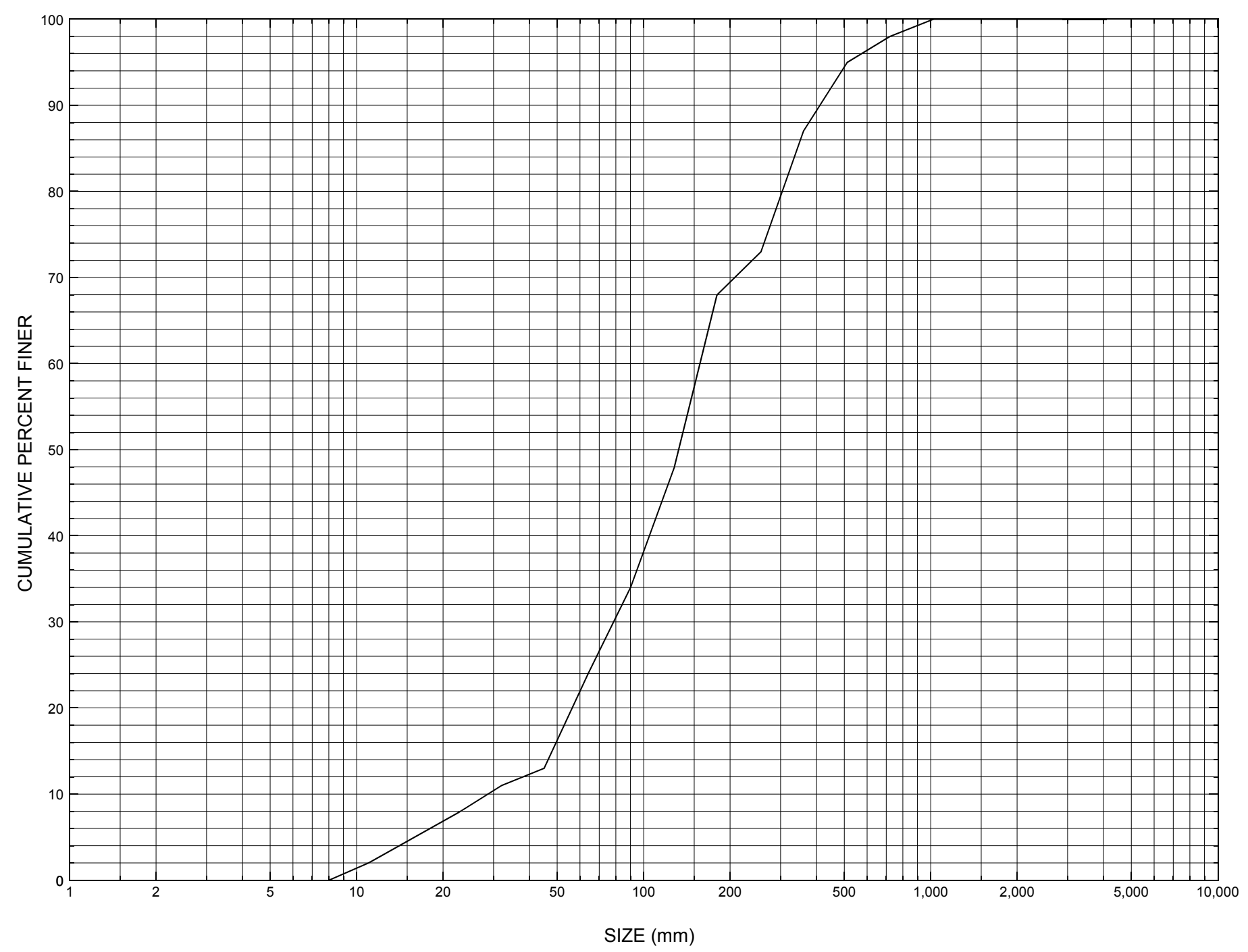

Appendix C. Bed material particle-size distribution for a pebble count transect at the approach cross-section for structure BLOOVT01050096, in Bloomfield, Vermont. 


\section{APPENDIX D: \\ HISTORICAL DATA FORM}




\section{Structure Number BLOOVT01050096}

\section{General Location Descriptive}

Data collected by (First Initial, Full last name) $\mathbf{E}$. BOEHMLER

Date $(M M / D D / Y Y) \_\mathbf{0 8} / \underline{\mathbf{0 5}} / \underline{\mathbf{9 4}}$

Highway District Number $(I-2 ; n n) \underline{09}$

Town (FIPS place code; I - 4; nnnnn) $\mathbf{0 6 3 2 5}$

Waterway ( I - 6) NULHEGAN RIVER

Route Number VT105

Topographic Map Bloomfield

Latitude (I - 16; nnnn.n) $\underline{44468}$
County (FIPS county code; I - 3; nnn)

Mile marker (I - 11; nnn.nnn) $\mathbf{0 0 0 7 5 0}$

Road Name (I - 7): -

Vicinity (I - 9) 3.4 MI W JCT. VT.102

Hydrologic Unit Code: $\mathbf{0 1 0 8 0 1 0 1}$

Longitude (i - 17; nnnnn.n) $\mathbf{7 1 4 0 6}$

\section{Select Federal Inventory Codes}

FHWA Structure Number $(I-8) \quad \mathbf{2 0 0 0 3 4 0 0 9 6 0 5 0 3}$

Maintenance responsibility $(I-21 ; n n) \quad \mathbf{0 1}$

Year built (I - 27; YYYY) 1992

Average daily traffic, ADT (I - 29; nnnnnn) $\underline{\mathbf{0 0 1 3 4 0}}$

Year of ADT (I - 30; YY) $\mathbf{9 2}$

Opening skew to Roadway (I - 34; nn) _24

Operational status $(I-41 ; X) \quad \mathbf{A}$

Structure type (I - 43; nnn) $\mathbf{3 0 2}$

Approach span structure type (I - 44; nnn) $\mathbf{0 0 0}$

Number of spans (I - 45; nnn) 001

Number of approach spans (I - 46; nnnn) $\mathbf{0 0 0 0}$

Comments:

Structural inspection report of 10/19/93 indicates the bridge is a steel stringer type. The abutments and wingwalls are in "like new" condition with footings not exposed and no settlement apparent. Additionally, there were no problems indicated for channel scour or embankment erosion.
Maximum span length (I - 48; nnnn) $\underline{\mathbf{0 0 7 1}}$

Structure length (I - 49; nnnnnn) $\underline{\mathbf{0 0 0 0 7 4}}$

Deck Width (I - 52; nn.n) $\mathbf{4 2 6}$

Channel \& Protection $(I-61 ; n) \underline{8}$

Waterway adequacy $(I-71 ; n)$

Underwater Inspection Frequency (I - 92B; XYY) _ N

Year Reconstructed (I - 106) $\mathbf{0 0 0 0}$

Clear span (nnn.n ft) $\quad \mathbf{0 6 0 . 0}$

Vertical clearance from streambed (nnn.n ft) $\underline{\mathbf{0 1 2 . 0}}$

Waterway of full opening $\left(n n n . n \mathrm{ft}^{2}\right) \quad \mathbf{7 1 6 . 0}$ 


\section{Bridge Hydrologic Data}

Is there hydrologic data available? $\underline{\mathbf{Y}}$ if No, type ctrl- $n$ VTAOT Drainage area $\left(m i^{2}\right): \underline{\mathbf{1 0 3 . 0}}$ Terrain character: Hilly

Stream character \& type: Straight

Streambed material: Cobbles and boulders

Discharge Data (cfs): $\quad \mathrm{Q}_{2.33} \frac{\mathbf{6 0 0}}{\mathbf{2 8 0 0}}$

$$
\mathrm{Q}_{50} \overline{\mathbf{2 8 0 0}}
$$

$\mathrm{Q}_{10} \frac{\mathbf{1 7 0 0}}{\mathbf{3 2 5 0}}$

$Q_{25} \frac{\mathbf{2 3 0 0}}{Q_{500}-}$

Record flood date (MM / DD / YY):

Water surface elevation (ft): -

Estimated Discharge (cfs): _ _ Velocity at Q $\underline{\mathbf{5 0}}(\mathrm{ft} / \mathrm{s}): \underline{\mathbf{8 . 4}}$

Ice conditions (Heavy, Moderate, Light) : Mod. Debris (Heavy, Moderate, Light): Heavy

The stage increases to maximum highwater elevation (Rapidly, Not rapidly): Rapidly

The stream response is (Flashy, Not flashy): Flashy

Describe any significant site conditions upstream or downstream that may influence the stream's stage: -

Watershed storage area (in percent): $18.3 \%$

The watershed storage area is: 2 (1-mainly at the headwaters; 2- uniformly distributed; 3-immediatly upstream oi the site)

Water Surface Elevation Estimates for Existing Structure:

\begin{tabular}{|l|l|c|c|l|l|}
\hline Peak discharge frequency & $Q_{2.33}$ & $Q_{10}$ & $Q_{25}$ & $Q_{50}$ & $Q_{100}$ \\
Water surface elevation (ft) $)$ & $\mathbf{1 0 3 8 . 0}$ & $\mathbf{1 0 4 0 . 3}$ & $\mathbf{1 0 4 1 . 1}$ & $\mathbf{1 0 4 1 . 8}$ & $\mathbf{1 0 4 2 . 3}$ \\
Velocity $(f t / \mathrm{sec})$ & $\mathbf{5 . 0}$ & $\mathbf{6 . 9}$ & $\mathbf{7 . 7}$ & $\mathbf{8 . 4}$ & $\mathbf{8 . 9}$ \\
\hline
\end{tabular}

Long term stream bed changes: -

Is the roadway overtopped below the $\mathrm{Q}_{100}$ ? (Yes, No, Unknown): $\mathbf{N} \quad$ Frequency: -

Relief Elevation $(f t)$ :

Discharge over roadway at $\mathrm{Q}_{100}\left(\mathrm{ft}^{3} / \mathrm{sec}\right)$ : -

Are there other structures nearby? (Yes, No, Unknown): Upstream distance (miles): Town: If No or Unknown, type ctrl-n os Highway No. : Structure No. :Year Built:

Clear span (ft): Clear Height (ft): Full Waterway $\left(f t^{2}\right)$ : 
Downstream distance (miles): $\underline{3.4}$ Town:

Highway No. : VT102

Year Built:

Clear span (ft): $\underline{\mathbf{1 2 8}}$ Clear Height $(f t): \underline{\mathbf{1 0 . 0}}$ Full Waterway $\left(f^{2}\right):-$

Comments:

\section{USGS Watershed Data}

Watershed Hydrographic Data

Drainage area $(D A) \underline{\mathbf{1 0 3 . 2}} \mathrm{mi}^{2}$

Watershed storage (ST) $\quad \mathbf{7 . 4}$ Structure No. : 9

Structure Type:

-

Bridge site elevation $\mathbf{1 0 5 1} \mathrm{ft}$ $\%$

Main channel length $\mathbf{1 7 . 6 0} \mathrm{mi}$

$10 \%$ channel length elevation $\mathbf{1 0 7 0}$

$\mathrm{ft} \quad 85 \%$ channel length elevation

1300 $\mathrm{ft}$

Main channel slope $(S) \quad \mathbf{1 7 . 4 3} \mathrm{ft} / \mathrm{mi}$

Watershed Precipitation Data

Average site precipitation in Average headwater precipitation in

Maximum 2yr-24hr precipitation event $(124,2)$ in

Average seasonal snowfall (Sn) $\mathrm{ft}$ 


\section{Bridge Plan Data}

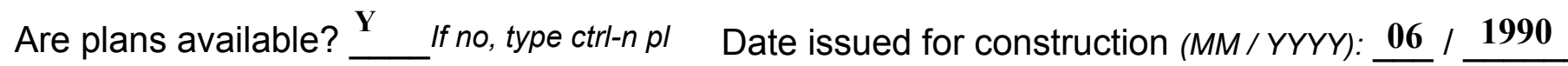
Project Number BRF 034-3(13) S Minimum channel bed elevation: 1033.0

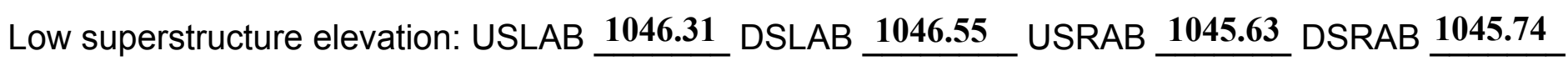
Benchmark location description:

BM\#1, pole, NET\&T no. 180/679/82, elevation 1050.89, 125 feet from rabut on left side of roadway going away from the bridge.

Reference Point (MSL, Arbitrary, Other): MSL Datum (NAD27, NAD83, Other): NGVD 1929

Foundation Type: 1

If 1: Footing Thickness _ _ Footing bottom elevation: $\underline{\mathbf{1 0 3 0 . 0}}$

If 2: Pile Type:___ (1-Wood; 2-Steel or metal; 3-Concrete) Approximate pile driven length: -

If 3: Footing bottom elevation:

Is boring information available? $\mathbf{N}$ If no, type ctrl-n bi Number of borings taken:

Foundation Material Type: $\mathbf{3}$ (1-regolith, 2-bedrock, 3-unknown)

Briefly describe material at foundation bottom elevation or around piles:

NO FOUNDATION MATERIAL INFORMATION

Comments: 


\section{Cross-sectional Data}

Is cross-sectional data available? $\mathbf{N}$ If no, type ctrl-n xs

Source (FEMA, VTAOT, Other)? -

Comments: NO CROSS SECTION INFORMATION

\begin{tabular}{|l|l|l|l|l|l|l|l|l|l|l|l|}
\hline Station & - & - & - & - & - & - & - & - & - & - & - \\
\hline Feature & - & - & - & - & - & - & - & - & - & - & - \\
\hline $\begin{array}{l}\text { Low cord } \\
\text { elevation }\end{array}$ & - & - & - & - & - & - & - & - & - & - & - \\
\hline $\begin{array}{l}\text { Bed } \\
\text { elevation }\end{array}$ & - & - & - & - & - & - & - & - & - & - & - \\
\hline $\begin{array}{l}\text { Low cord to } \\
\text { bed length }\end{array}$ & - & - & - & - & - & - & - & - & - & - & - \\
\hline Station & - & - & - & - & - & - & - & - & - & - & - \\
\hline Feature & - & - & - & - & - & - & - & - & - & - & - \\
\hline $\begin{array}{l}\text { Low cord } \\
\text { elevation }\end{array}$ & - & - & - & - & - & - & - & - & - & - & - \\
\hline $\begin{array}{l}\text { Bed } \\
\text { elevation }\end{array}$ & - & - & - & - & - & - & - & - & - & - & - \\
\hline $\begin{array}{l}\text { Low cord to } \\
\text { bed length }\end{array}$ & - & - & - & - & - & - & - & - & - & - & - \\
\hline
\end{tabular}

Source (FEMA, VTAOT, Other)?

Comments: NO CROSS SECTION INFORMATION

\begin{tabular}{|l|l|l|l|l|l|l|l|l|l|l|l|}
\hline Station & - & - & - & - & - & - & - & - & - & - & - \\
\hline Feature & - & - & - & - & - & - & - & - & - & - & - \\
\hline $\begin{array}{l}\text { Low cord } \\
\text { elevation }\end{array}$ & - & - & - & - & - & - & - & - & - & - & - \\
\hline $\begin{array}{l}\text { Bed } \\
\text { elevation }\end{array}$ & - & - & - & - & - & - & - & - & - & - & - \\
\hline $\begin{array}{l}\text { Low cord to } \\
\text { bed length }\end{array}$ & - & - & - & - & - & - & - & - & - & - & - \\
\hline Station & - & - & - & - & - & - & - & - & - & - & - \\
\hline Feature & - & - & - & - & - & - & - & - & - & - & - \\
\hline $\begin{array}{l}\text { Low cord } \\
\text { elevation }\end{array}$ & - & - & - & - & - & - & - & - & - & - & - \\
\hline $\begin{array}{l}\text { Bed } \\
\text { levation }\end{array}$ & - & - & - & - & - & - & - & - & - & - & - \\
\hline $\begin{array}{l}\text { Low cord to } \\
\text { bed length }\end{array}$ & - & - & - & - & - & - & - & - & - & - & - \\
\hline
\end{tabular}




\section{APPENDIX E: \\ LEVEL I DATA FORM}


U. S. Geological Survey

Bridge Field Data Collection and Processing Form

Qa/Qc Check by: TS Date: 10-26-95

\section{Structure Number}

BLOOVT01050096 Date: 10-27-95 Computerized by: TS

Reviewd by: JDA Date: 6-26-96

\section{A. General Location Descriptive}

1. Data collected by (First Initial, Full last name) M. IVANOFF

2. Highway District Number 09

County Essex (009)

Waterway $(I-6)$ Nulhegan River

Route Number VT 105

3. Descriptive comments:

Bridge is located 3.4 miles west of junction with VT 102
Mile marker $\mathbf{0 0 0 7 5 0}$

Town Bloomfield

Road Name VT 105

Hydrologic Unit Code: $\mathbf{0 1 0 8 0 1 0 1}$

\section{B. Bridge Deck Observations}
4. Surface cover... LBUS 5
RBUS 5
LBDS 6
RBDS 6
Overall 6

(2b us,ds,lb,rb: 1- Urban; 2- Suburban; 3- Row crops; 4- Pasture; 5- Shrub- and brushland; 6- Forest; 7- Wetland)
5. Ambient water surface... US 1
UB 2
DS 2
(1- pool; 2- riffle)

6. Bridge structure type 1 (1- single span; 2- multiple span; 3- single arch; 4- multiple arch; 5-cylindrical culvert; 6- box culvert; or 7- other)
7. Bridge length $\mathbf{7 4}$
(feet)
Span length $\mathbf{7 1}$
(feet)
Bridge width 42.6 (feet)

\section{Road approach to bridge:}
8. LB 2 RB 0
( 0 even, 1- lower, 2- higher)
9. LB 1
RB 1
(1-Paved, 2- Not paved)

10. Embankment slope (run / rise in feet / foot)

US left

0.0:1

US right

0.0:1

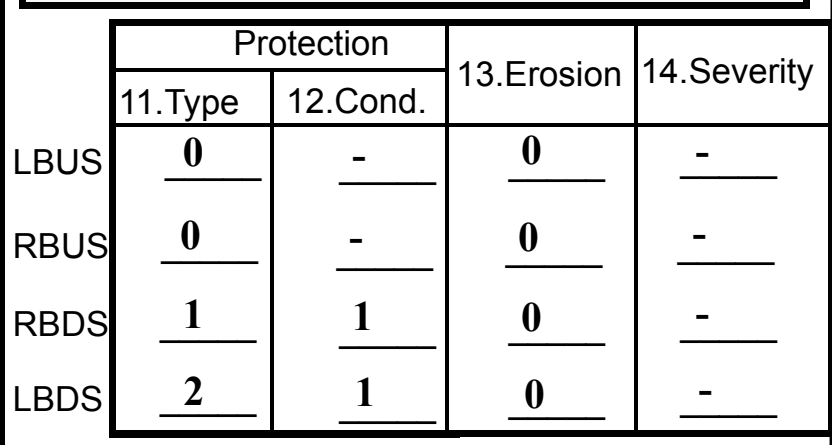

Bank protection types: 0- none; 1- < 12 inches;

2- < 36 inches; 3- < 48 inches;

4- < 60 inches; 5- wall / artificial levee

Bank protection conditions: 1- good; 2- slumped;

3- eroded; 4- failed

Erosion: 0 - none; 1- channel erosion; 2 -

road wash; 3- both; 4- other

Erosion Severity: 0 - none; 1- slight; 2- moderate; 3- severe

\section{Channel approach to bridge (BF):}

15. Angle of approach: $\underline{40}$

16. Bridge skew: $\mathbf{1 0}$

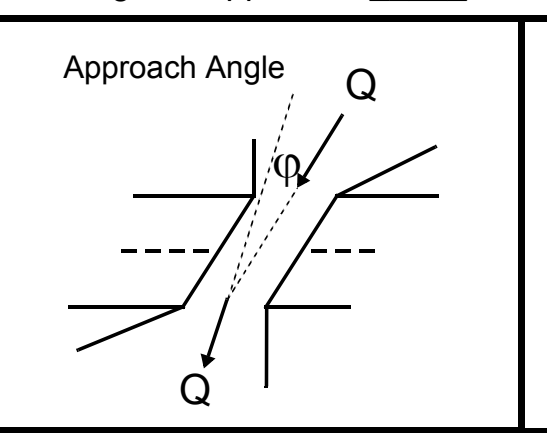

17. Channel impact zone 1:

Where? RB (LB, RB)

Range? 80 feet US

Channel impact zone 2:

Where? RB (LB, RB)

Range? $\underline{30 \quad \text { feet DS }}$

Impact Severity: 0- none to very slight; 1- Slight; 2- Moderate; 3- Severe
Bridge Skew Angle

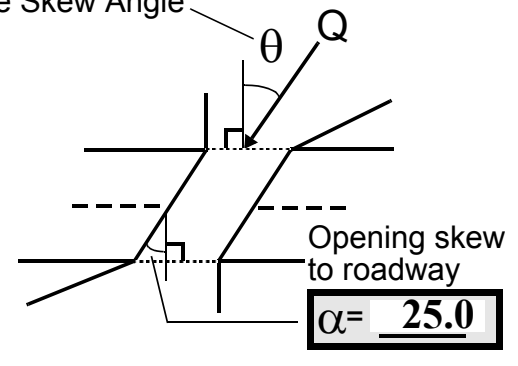

\section{Exist? $\mathbf{Y}(Y$ or $N)$}

Severity 2

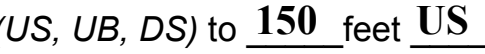

Exist? $\mathbf{Y}(Y$ or $N)$

Severity $\underline{2}$

, UB, DS) to $\underline{90 \quad \text { feet }}$ DS 
18. Level II Bridge Type: 1a, 4

1a- Vertical abutments with wingwalls

1 b- Vertical abutments without wingwalls

2- Vertical abutments and wingwalls, sloping embankment

Wingwalls perpendicular to abut. face

3- Spill through abutments

4- Sloping embankment, vertical wingwalls and abutments

1 a with wingwalls

Wingwall angle less than $90^{\circ}$.

19. Bridge Deck Comments (surface cover variations, measured bridge and span lengths, bridge type variations, approach overflow width, etc.)

4. LBUS- gravel road runs along top of bank

RBUS- gravel parking area above bank in vicinity of bridge

\section{Upstream Channel Assessment}

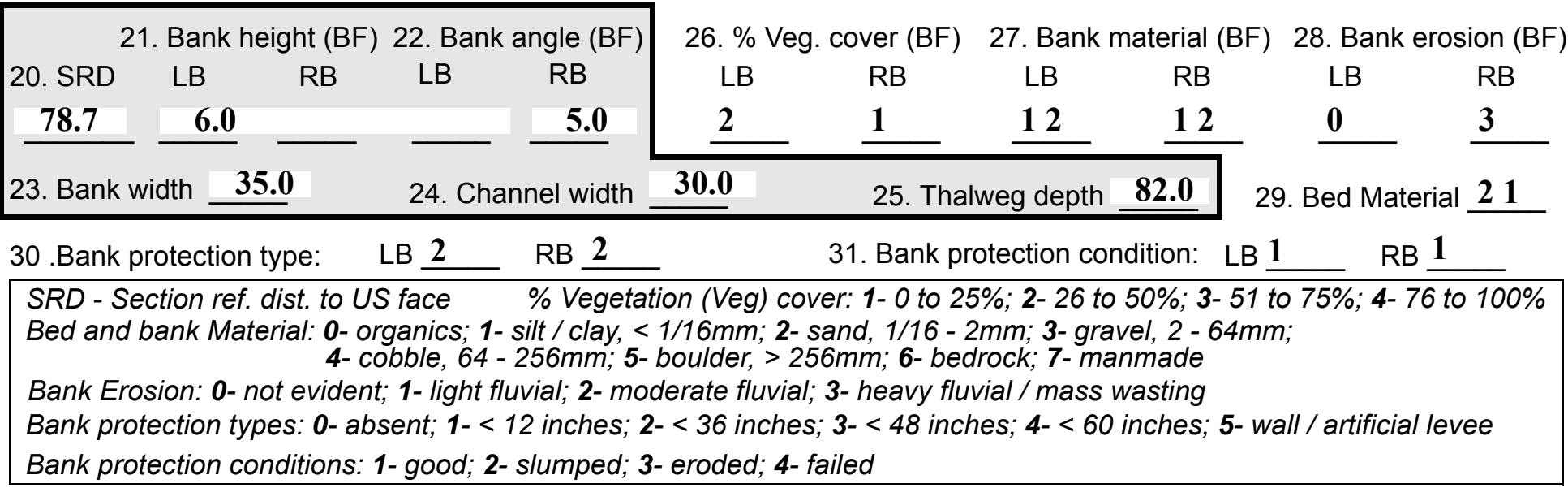

32. Comments (bank material variation, minor inflows, protection extent, etc.):

29. Channel bed is cobble from the bridge to 75 feet US.

30. Left bank protection extends from bridge deck to 125 feet US. Right bank protection extends from bridge deck to 75 feet US. 
37. Material: 2

38. Point or side bar comments (Circle Point or Side; Note additional bars, material variation, status, etc.):

Point bar composed of sand.

39. Is a cut-bank present? $\mathbf{Y}$ (Y or if $N$ type ctrl-n $c b)$

41. Mid-bank distance: 250

43. Bank damage: 3

42. Cut bank extent: 80
40. Where? $\underline{\mathbf{R B}}$ (LB or RB) feet $\underline{\text { US }}$ (US, UB) to $\underline{\mathbf{4 0 0}}$ feet DS (US, UB, DS)

44. Cut bank comments (eg. additional cut banks, protection condition, etc.):

Cut bank is opposite of point bar.

45. Is channel scour present? $\mathbf{Y}$ (Y or if $N$ type ctrl-n cs) 46. Mid-scour distance: 125

47. Scour dimensions: Length 150 Width $\underline{\mathbf{4 0}}$ Depth: $\underline{4}$ Position $\underline{15} \%$ LB to $\underline{\mathbf{2 5}} \%$ RB

48. Scour comments (eg. additional scour areas, local scouring process, etc.):

Channel scour starts at channel center, 50 feet US of bridge, and continues some 200 feet US of bridge along base of stone fill on left bank.

49. Are there major confluences? $\mathbf{N}$

51. Confluence 1: Distance Confluence 2: Distance -
54. Confluence comments (eg. confluence name):
( $Y$ or if $N$ type ctrl-n $m c)$

52. Enters on -

Enters on ( $L B$ or $R B)$ ( $L B$ or $R B)$

NO MAJOR CONFLUENCES

\section{Under Bridge Channel Assessment}

55. Channel restraint (BF)? LB 2

56. Height (BF)
LB RB
$\mathbf{6 5 . 0}-$
58. Bank width (BF) -
(1- natural bank; 2- abutment; 3- artificial levee)

53. Type(1- perennial; 2- ephemeral)

Type (1-perennial; 2- ephemeral)

Bed and bank Material: 0- organics; 1- silt / clay, < 1/16mm; 2- sand, 1/16 - 2mm; 3- gravel, 2 - 64mm; 4- cobble, 64 - 256mm; 5- boulder, > 256mm; 6- bedrock; 7- manmade

Bank Erosion: 0- not evident; 1- light fluvial; 2- moderate fluvial; 3- heavy fluvial / mass wasting

64. Comments (bank material variation, minor inflows, protection extent, etc.):

453

\section{NO COMMENTS}


65. Debris and Ice Is there debris accumulation?

$(Y$ or $N)$ 66. Where? $\underline{Y}$

(1- Upstream; 2- At bridge; 3- Both)

67. Debris Potential 1 (1-Low; 2-Moderate; 3- High)

68. Capture Efficiency 3

(1-Low; 2- Moderate; 3- High)

69. Is there evidence of ice build-up? 1 (Y or $N)$

Ice Blockage Potential $\underline{\mathbf{Y}}$

(1- Low; 2- Moderate; 3- High)

70. Debris and Ice Comments:

2

67. Debris noted along US right bank, also mentioned in historical form.

\begin{tabular}{|l|c|c|c|c|c|c|c|c|}
\hline Abutments & $\begin{array}{c}\text { 71. Attack } \\
\angle \mathrm{BF})\end{array}$ & $\begin{array}{c}\text { 72. Slope } \\
(\mathrm{Qmax})\end{array}$ & $\begin{array}{l}\text { 73. Toe } \\
\text { loc. (BF) }\end{array}$ & $\begin{array}{c}\text { 74. Scour } \\
\text { Condition }\end{array}$ & $\begin{array}{c}\text { 75. Scour } \\
\text { depth }\end{array}$ & $\begin{array}{c}\text { 76. Exposure } \\
\text { depth }\end{array}$ & 77. Material & 78. Length \\
\hline LABUT & & $\mathbf{0}$ & $\mathbf{9 0}$ & $\mathbf{2}$ & $\mathbf{0}$ & $\mathbf{0}$ & $\mathbf{0}$ & $\mathbf{9 0 . 0}$ \\
\hline RABUT & $\mathbf{1}$ & $\mathbf{0}$ & $\mathbf{9 0}$ & & & $\mathbf{2}$ & $\mathbf{0}$ & $\mathbf{7 5 . 0}$ \\
\hline
\end{tabular}

Pushed: $L B$ or RB

Toe Location (Loc.): 0- even, 1- set back, 2- protrudes

Scour cond.: 0- not evident; 1- evident (comment); 2- footing exposed; 3-undermined footing; 4- piling exposed; 5- settled; 6- failed

Materials: 1- Concrete; 2- Stone masonry or drywall; 3- steel or metal; 4- wood

79. Abutment comments (eg. undermined penetration, unusual scour processes, debris, etc.):

$\mathbf{0}$

0

1

\section{NO COMMENTS}

80. Wingwalls:

Exist? Material? Scour Scour Exposure Angle? Length? Condition? depth? depth?

USLWW:

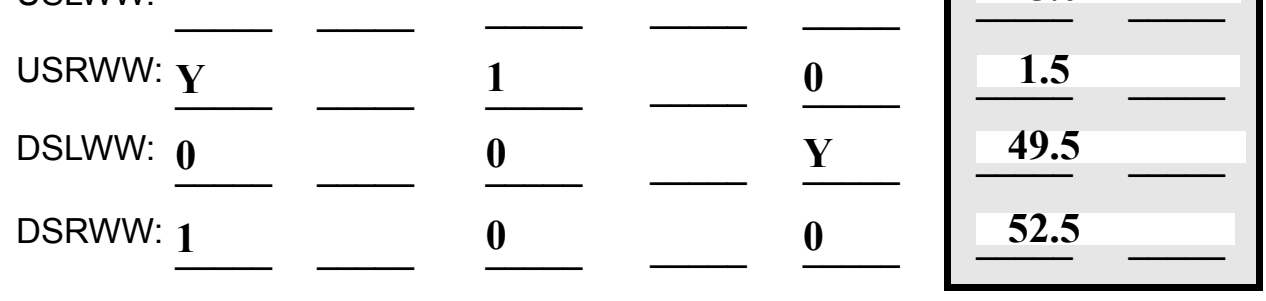

Wingwall materials: 1- Concrete; 2- Stone masonry or drywall; 3- steel or metal; 4- wood

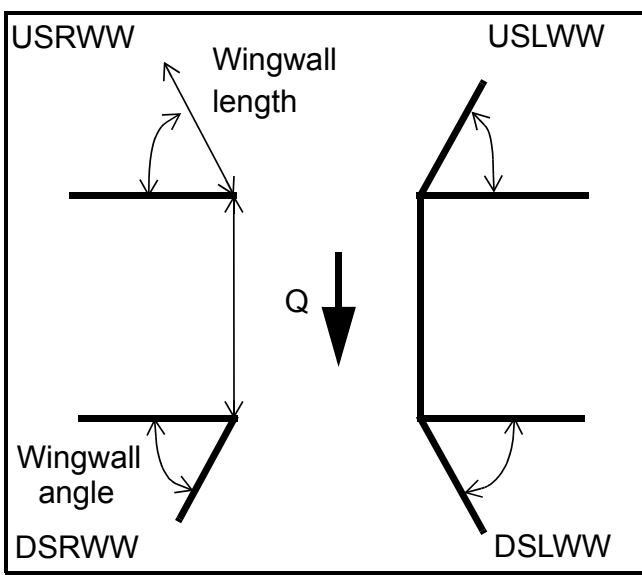

82. Bank / Bridge Protection:

\begin{tabular}{|l|l|l|l|l|l|l|l|l|}
\hline Location & USLWW & USRWW & LABUT & RABUT & LB & RB & DSLWW & DSRWW \\
\hline Type & $\mathbf{0}$ & $\mathbf{0}$ & $\mathbf{Y}$ & $\mathbf{0}$ & $\mathbf{1}$ & $\mathbf{1}$ & $\mathbf{1}$ & $\mathbf{1}$ \\
\hline Condition & $\mathbf{Y}$ & $\mathbf{0}$ & $\mathbf{1}$ & $\mathbf{0}$ & $\mathbf{1}$ & $\mathbf{1}$ & $\mathbf{1}$ & $\mathbf{1}$ \\
\hline Extent & $\mathbf{1}$ & $\mathbf{0}$ & $\mathbf{0}$ & $\mathbf{2}$ & $\mathbf{2}$ & $\mathbf{2}$ & $\mathbf{2}$ & $\mathbf{0}$ \\
\hline
\end{tabular}

Bank / Bridge protection types: 0- absent; 1- < 12 inches; 2- < 36 inches; 3- < 48 inches; 4- < 60 inches; 
83. Wingwall and protection comments (eg. undermined penetration, unusual scour processes, etc.):

-
-
0
-
-
2
1
1
2
1
1

Piers:

84. Are there piers? NO (Y or if N type ctrl-n pr)

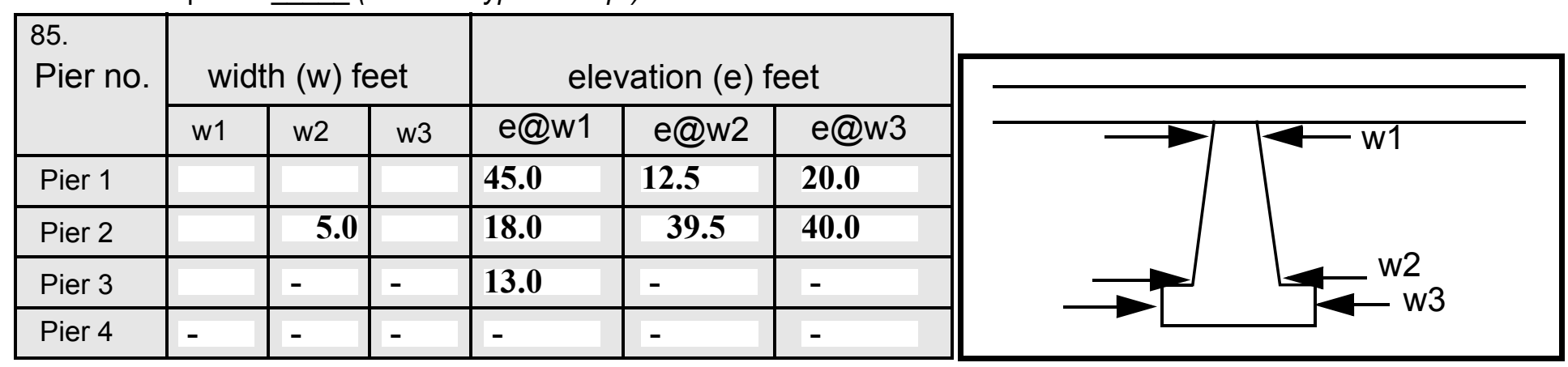

\begin{tabular}{|c|c|c|c|c|}
\hline Level 1 Pier Descr. & 1 & 2 & 3 & 4 \\
\hline 86. Location (BF) & $\mathrm{CO}$ & & - & - \\
\hline 87. Type & MM & & - & - \\
\hline 88. Material & ENT & $\mathbf{N}$ & - & - \\
\hline 89. Shape & $\mathbf{S}$ & - & - & - \\
\hline 90. Inclined? & & - & - & - \\
\hline 91. Attack $\angle(B F)$ & & - & - & - \\
\hline 92. Pushed & & - & - & - \\
\hline 93. Length (feet) & - & - & - & - \\
\hline 94. \# of piles & & - & - & - \\
\hline 95. Cross-members & & - & - & - \\
\hline 96. Scour Condition & & - & - & - \\
\hline 97. Scour depth & & - & - & - \\
\hline 98. Exposure depth & & - & - & - \\
\hline
\end{tabular}

LFP, LTB, LB, MCL, MCM, MCR, RB, RTB, RFP

1- Solid pier, 2- column, 3- bent

1-Wood; 2- concrete; 3- metal; 4- stone

1- Round; 2- Square; 3- Pointed

Y-yes; $N-$ no

$L B$ or $R B$

0- none; 1- laterals; 2- diagonals; 3- both

0- not evident; 1- evident (comment);

2- footing exposed; 3- piling exposed;

4- undermined footing; 5- settled; 6 - failed 
99. Pier comments (eg. undermined penetration, protection and protection extent, unusual scour processes, etc.):

-
-
-
-
-
-
-
-
-

100.

\section{E. Downstream Channel Assessment}

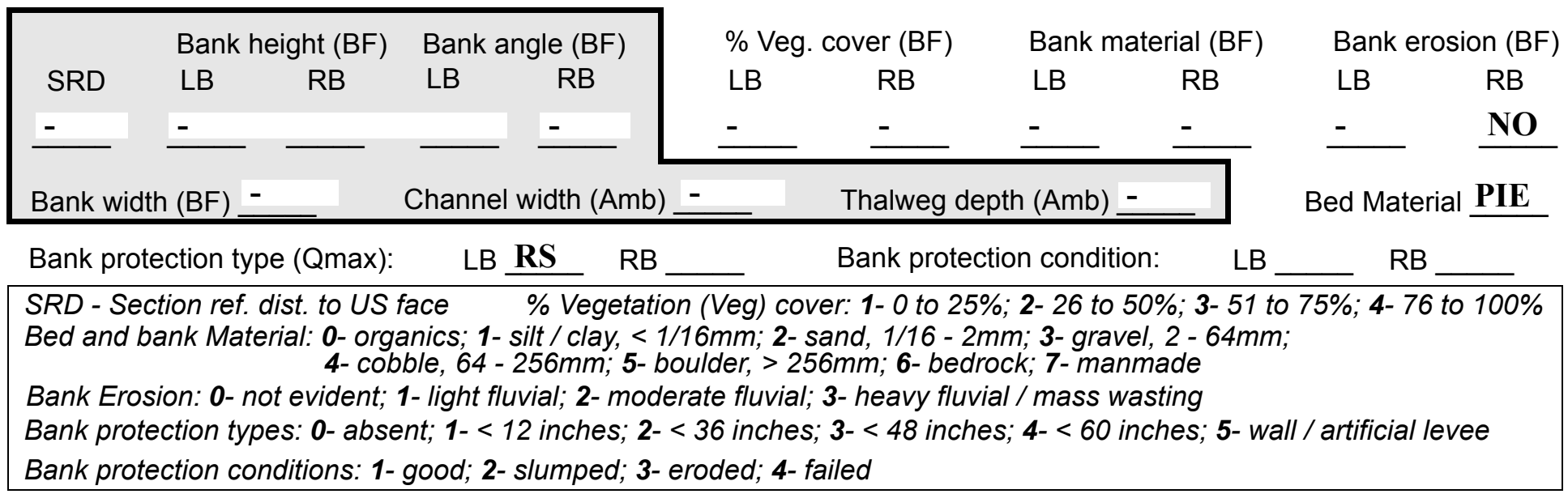

Comments (eg. bank material variation, minor inflows, protection extent, etc.):

4

4

431

54

1

0

543

2

2

101. Is a drop structure present? 1 ( $Y$ or $N$, if $N$ type ctrl-n ds) 102. Distance: ___ feet

103. Drop: __ feet 104. Structure material: 1 (1- steel sheet pile; 2- wood pile; 3- concrete; 4- other) 105. Drop structure comments (eg. downstream scour depth):

Bank protection consists of stone fill. Left bank protection extends 80 feet downstream, while right bank protection extends 50 feet downstream. Beyond protection banks are lined with native stone and boulder. Left bank is eroded DS of protection, a description follows in "cut-bank" section. 
106. Point/Side bar present? (Y or $N$. if $N$ type ctrl-n pb)Mid-bar distance:

Mid-bar width:

Point bar extent: feet

(US, UB, DS) to feet (US, UB, DS) positioned $\%$ LB to $\% \mathrm{RB}$ Material: $\mathbf{N}$

Point or side bar comments (Circle Point or Side; note additional bars, material variation, status, etc.):

NO DROP STRUCTURE

Is a cut-bank present? (Y or if $N$ type ctrl- $n$ cb) Where? (LB or $R B)$

Mid-bank distance:

Cut bank extent: $\mathbf{N}$ feet (US, UB, DS) to feet -

Bank damage: (1- eroded and/or creep; 2- slip failure; 3- block failure)

Cut bank comments (eg. additional cut banks, protection condition, etc.):

-

-

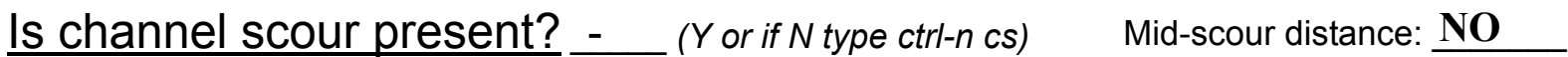

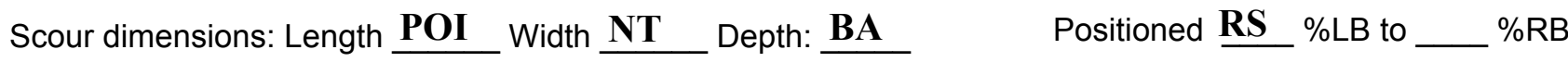
Scour comments (eg. additional scour areas, local scouring process, etc.):

$\mathbf{Y}$

LB

Are there major confluences? $\mathbf{1 2}$ ( $Y$ or if $N$ type ctrl- $n$ mc)

How many? $\underline{\mathbf{0}}$

Confluence 1: Distance 90 Enters on DS ( $L B$ or RB)

Type 150 (1- perennial; 2- ephemeral)

Confluence 2: Distance DS Enters on 1 ( $L B$ or $R B)$

Type Ran (1- perennial; 2- ephemeral)

Confluence comments (eg. confluence name):

domly placed boulder and stone along base of cut-bank, boulder/stone density increases beyond 150 feet DS.

\section{F. Geomorphic Channel Assessment}

107. Stage of reach evolution

1- Constructed

2- Stable

3- Aggraded

4- Degraded

5- Laterally unstable

6- Vertically and laterally unstable 
108. Evolution comments (Channel evolution not considering bridge effects; See HEC-20, Figure 1 for geomorphic descriptors): $\mathbf{N}$

$-$

$-$

$-$

$-$

$-$

$-$

NO CHANNEL SCOUR 


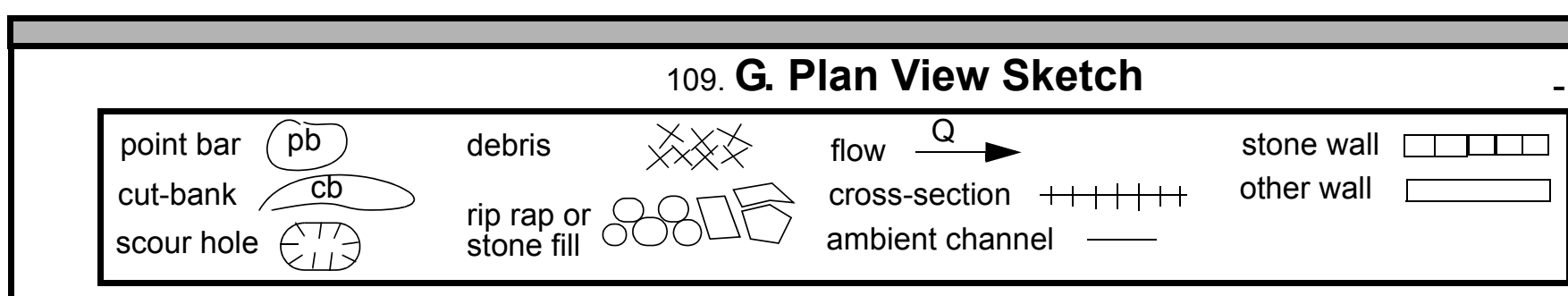


APPENDIX F:

SCOUR COMPUTATIONS 
SCOUR COMPUTATIONS

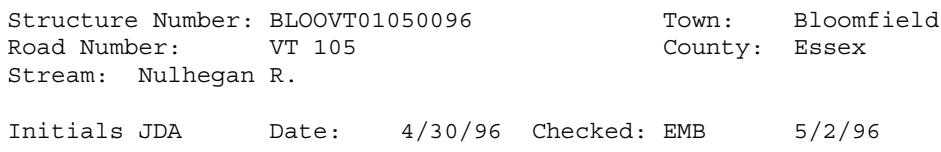

Analysis of contraction scour, live-bed or clear water?

\begin{tabular}{|c|c|c|c|}
\hline \multicolumn{4}{|l|}{ Approach Section } \\
\hline Characteristic & $100 \mathrm{yr}$ & $500 \mathrm{yr}$ & other $Q$ \\
\hline Total discharge, cfs & 5100 & 7000 & 0 \\
\hline Main Channel Area, ft2 & 692 & 875 & 0 \\
\hline Left overbank area, ft2 & 0 & 7 & 0 \\
\hline Right overbank area, ft2 & 0 & 0 & 0 \\
\hline Top width main channel, ft & 89 & 101 & 0 \\
\hline Top width L overbank, ft & 0 & 31 & 0 \\
\hline Top width $\mathrm{R}$ overbank, ft & 0 & 0 & 0 \\
\hline D50 of channel, ft & 0.43451 & 0.43451 & 0 \\
\hline D50 left overbank, ft & -- & -- & 0 \\
\hline D50 right overbank, ft & -- & -- & 0 \\
\hline $\mathrm{y}_{1}$, average depth, $\mathrm{MC}$, ft & 7.8 & 8.7 & ERR \\
\hline Y1, average depth, LOB, ft & ERR & 0.2 & ERR \\
\hline $\mathrm{y}^{1}$, average depth, ROB, ft & ERR & ERR & ERR \\
\hline Total conveyance, approach & 86664 & 118072 & 0 \\
\hline Conveyance, main channel & 86664 & 117997 & 0 \\
\hline Conveyance, LOB & 0 & 75 & 0 \\
\hline Conveyance, ROB & 0 & 0 & 0 \\
\hline Percent discrepancy, conveyance & 0.0000 & 0.0000 & ERR \\
\hline Qm, discharge, MC, cfs & 5100.0 & 6995.6 & ERR \\
\hline Q1, discharge, LOB, Cfs & 0.0 & 4.4 & ERR \\
\hline Qr, discharge, ROB, Cfs & 0.0 & 0.0 & ERR \\
\hline $\mathrm{Vm}$, mean velocity $\mathrm{MC}$, ft/s & 7.4 & 8.0 & ERR \\
\hline Vl, mean velocity, LOB, ft/s & ERR & 0.6 & ERR \\
\hline Vr, mean velocity, ROB, ft/s & ERR & ERR & ERR \\
\hline Vc-m, crit. velocity, $M C$, ft/s & 12.0 & 12.2 & $\mathrm{~N} / \mathrm{A}$ \\
\hline Vc-l, crit. velocity, LOB, ft/s & ERR & ERR & $\mathrm{N} / \mathrm{A}$ \\
\hline Vc-r, crit. velocity, ROB, ft/s & ERR & ERR & $\mathrm{N} / \mathrm{A}$ \\
\hline \multicolumn{4}{|l|}{ Results } \\
\hline \multicolumn{4}{|c|}{ Live-bed(1) or Clear-Water(0) Contraction Scour? } \\
\hline Main Channel & 0 & 0 & $\mathrm{~N} / \mathrm{A}$ \\
\hline Left Overbank & $\mathrm{N} / \mathrm{A}$ & $\mathrm{N} / \mathrm{A}$ & $\mathrm{N} / \mathrm{A}$ \\
\hline Right Overbank & $\mathrm{N} / \mathrm{A}$ & $\mathrm{N} / \mathrm{A}$ & $\mathrm{N} / \mathrm{A}$ \\
\hline
\end{tabular}


Clear water Contraction Scour in MAIN CHANNEL

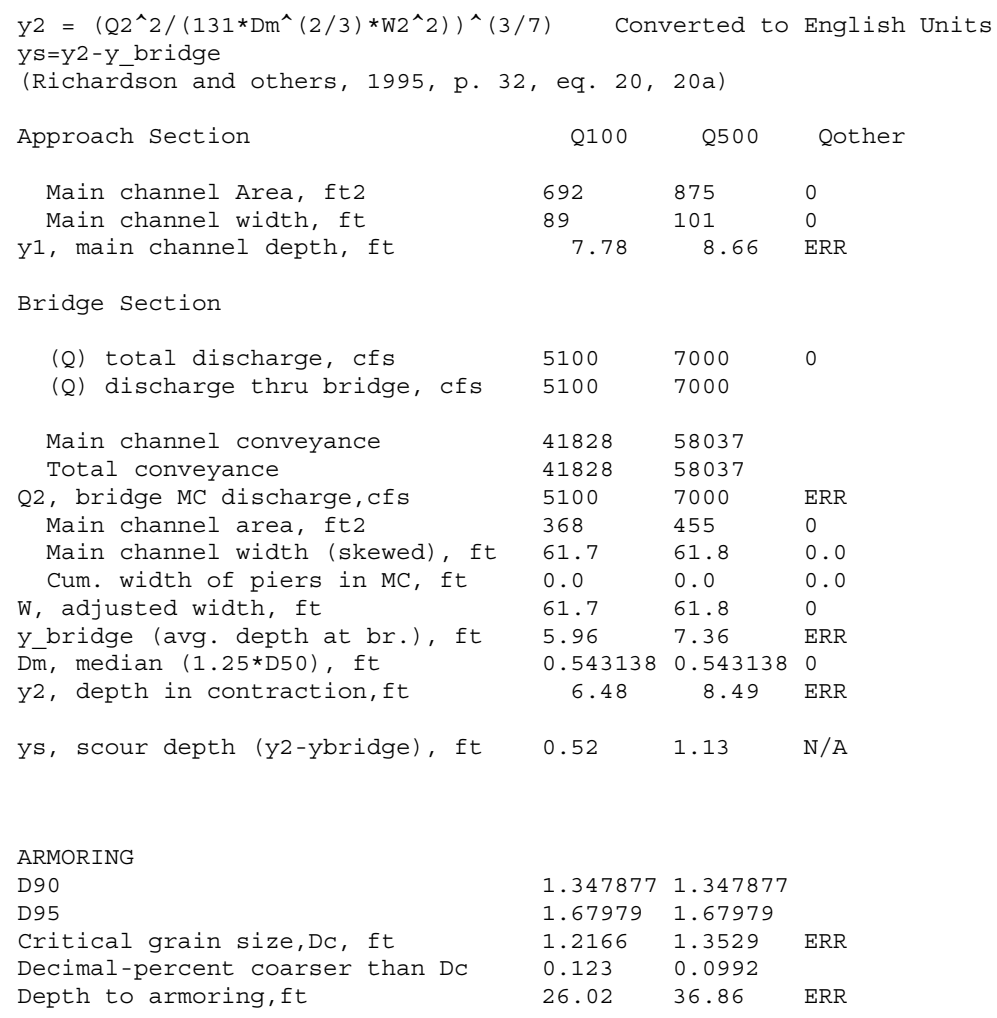




\section{Abutment Scour}

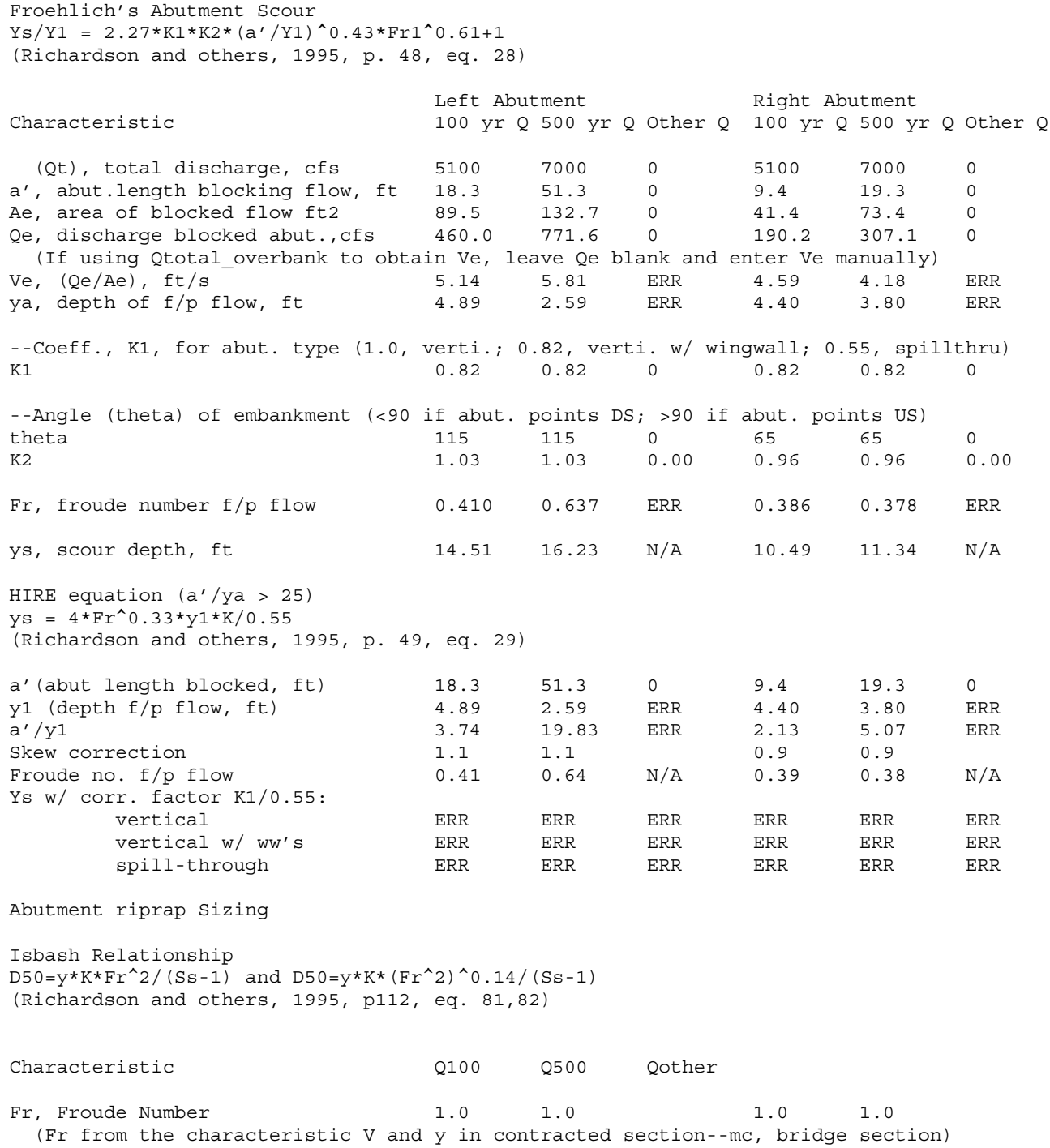


$y$, depth of flow in bridge, ft

6.0

7.4

Median Stone Diameter for riprap at: left abutment Fr $<=0.8$ (vertical abut.)

Fr>0.8 (vertical abut.)

ERR

ERR

0.00
ERR
6.0

right abutment, ft

ERR ERR

2.51 ERR 